\title{
RACHADURAS NO MURO INTERAGINDO COM O MOVIMENTO PELA PAZ NA PALESTINA E EM ISRAEL
}

\section{CRAKS IN THE WALL MEETING THE PEACE MOVEMENT IN PALESTINE AND ISRAEL}

\section{Eliceli Katia Bonan ${ }^{1}$}

\begin{abstract}
Resumo: 0 presente trabalho é um relato de viagem de pesquisa para conhecer o movimento pela paz em Israel e na Palestina. A viagem ocorreu entre os meses de dezembro de 2016 e fevereiro de 2017 e a pesquisadora morou na cidade de Belém durante todo o período, visitando Israel e outros locais da Cisjordânia regularmente. A pesquisa é parte da dissertação apresentada para obtenção do título de mestre em Relações Internacionais da Universidade de São Paulo - IRI-USP. 0 relato foca em experiências pessoais, os desafios da pesquisa e outros aspectos da realidade vivida principalmente na Cisjordânia.
\end{abstract}

Palavras-chave: movimento pela paz, Israel, Palestina, viagem de pesquisa, Cisjordânia.

\begin{abstract}
This is a research trip report about the peace movement in Israel and Palestine. The trip occurred between December 2016 and February 2017, and the author lived in the city of Bethlehem throughout the period, visiting Israel and other places in the West Bank on a regular basis. The research is part of the dissertation presented to obtain the master's degree title in International Relations at the University of São Paulo - IRI-USP. The report focuses on personal experiences, research challenges and other aspects of the reality lived mainly in the West Bank.
\end{abstract}

Key-words: peace movement, Israel, Palestine, research trip, West Bank.

O casal que me recebeu em Jaffa achou difícil entender meu interesse em viajar para Belém, na Cisjordânia. "Nasci e cresci em Tel-Aviv e em 30 anos jamais fui até lá. Não há nada para ver, só pobreza e guerra. Aliás, é proibido para mim e extremamente perigoso", disse-me Efrat, minha anfitriã. Seu marido, um judeu americano, considerou curioso que alguém se arriscasse a fazer tal viagem. Por ter passaporte americano, além do israelense, sua entrada é permitida em Belém, "mas é muito perigoso e não me parece interessante. Nem há meios de se chegar à cidade, a não ser com carro próprio. Perguntei a alguns de meus amigos sobre as rotas, para ajudar você, mas nenhum deles jamais viajou para lá. É muito remoto".

Tinha ouvido muitos estereótipos sobre a Cisjordânia. De fato, apesar de ser um percurso de pouco mais de $70 \mathrm{Km}$ a partir de Tel-Aviv até Belém, as distâncias entre o que encontrei nos dois lugares são imensas. Uma marca da descomunal diversidade deste pequeno pedaço de território entre o mar Mediterrâneo e a Jordânia, disputado entre israelenses e palestinos ${ }^{2}$ há quase um século.

\footnotetext{
${ }^{1}$ Eliceli Katia Bonan é jornalista formada pela UNOCHAPECÓ e mestranda em Relações Internacionais pela Universidade de São Paulo - USP. Lattes: http://lattes.cnpq.br/1952609668341084. Contato: elicelikb@ gmail.com. A pesquisa aqui relatada é parte de sua dissertação de mestrado.

${ }^{2}$ Opto por falar em "israelenses e palestinos" em vez de judeus e árabes, ou afins, pois, conforme observado na pesquisa, é a autodefinição mais usada neste momento.
} 
Meu propósito em fazer tal viagem foram interesses acadêmicos. Em minha dissertação de mestrado escrevo sobre as iniciativas de diálogo entre a sociedade civil israelenses e palestina após o fracasso nas negociações de paz, em 2000, bem como sobre as dificuldades que encontram para seguirem sendo relevantes. Essas iniciativas envolvem desde ONGs até grupos religiosos, acadêmicos e ativistas políticos. Para coletar dados de pesquisa, passei dez semanas na Terra Santa, entre dezembro de 2016 e fevereiro de 2017. Nesse período, visitei 14 diferentes Organizações da Sociedade Civil (OSCs) e conduzi entrevistas com cerca de 20 ativistas pela paz, além de participar de diversas atividades dos grupos e experimentar o dia a dia de uma área de conflito.

Grupos de diálogo e iniciativas conjuntas por parte da sociedade civil são comuns nos processos de resolução de conflitos armados. Eles emergem para preparar o público para a paz, encorajar a discussão aberta, fortalecer a conscientização cultural e, em última análise, criar propostas que possam influenciar os tomadores de decisão. Por si só, o diálogo não oficial não altera um conflito, mas é um importante passo. Para israelenses e palestinos ansiosos por um acordo de paz, na década de 1990, os contatos da sociedade civil mostraram a existência de um parceiro, o que foi de grande importância para o processo de paz que se seguiu. Criou-se um clima público para a paz, que eventualmente atingiu os níveis oficiais e culminou nos Acordos de Oslo.

Os anos que antecederam Oslo e durante as negociações também são os anos da Era de Ouro do movimento pela paz em Israel e Palestina. No entanto, o fracasso dessas conversações mudou a paisagem política local. 0 conflito intensificou-se, as sociedades

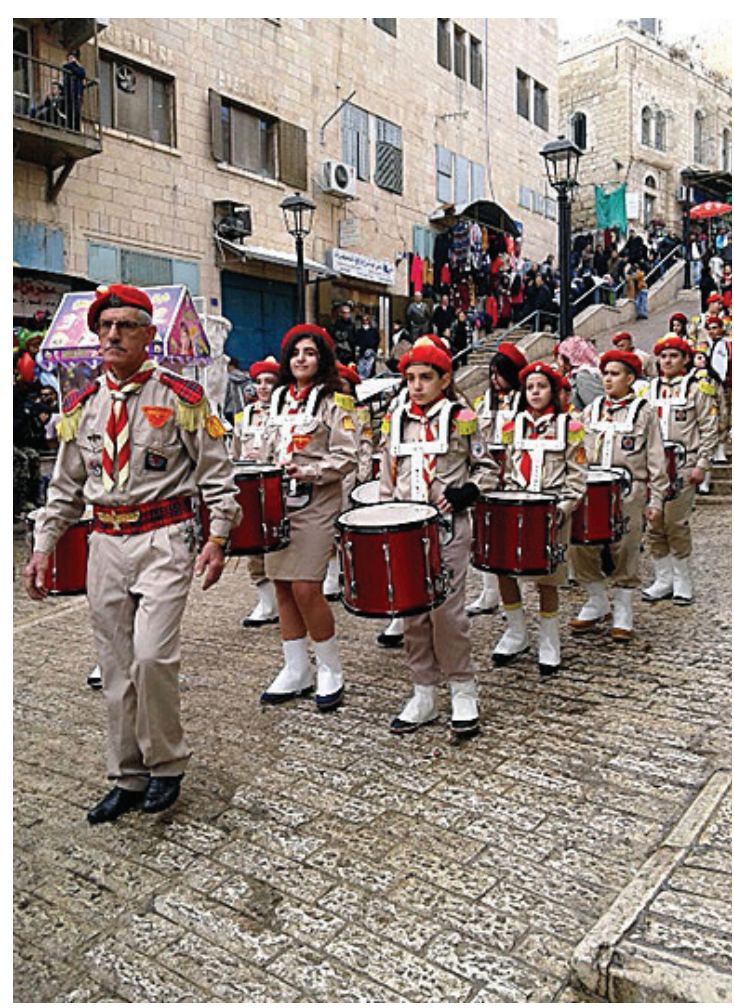

Apresentação de bandas nas ruas de Belém como atração turística durante a semana do Natal. se distanciaram e hoje o movimento pela paz luta para sobreviver e manter sua relevância.

Optei por ficar em Belém mais pelo contato sólido que consegui de acomodação para as dez semanas do que por qualquer outra razão. Só mais tarde percebi como estar em Belém fez-me experimentar o conflito de uma forma que não seria possível se estivesse hospedada em Jerusalém, por exemplo. 0 Muro da Cisjordânia e a difícil realidade da ocupação é quase imperceptível aos israelenses. Mas são imensos quando se está "do outro lado".

Não tinha uma grande quantidade de informações sobre a cidade antes de viajar. Mas ouvi histórias negativas o suficiente para saber que não devia mencionar a Cisjordânia ao passar pela imigração israelense, na entrada do país. Pelas leituras que realizei, 


\section{relato de campo}

sabia que o movimento de paz não é bem visto pelo atual governo. Aqueles que optam por dialogar com palestinos são considerados inimigos de Israel. Não sabia se as histórias eram verdadeiras - de pessoas que tiveram passaporte confiscado, foram presas, deportadas simplesmente por estarem junto com os ativistas pela paz protestando contra a ocupação -, não sabia se poderia acontecer comigo. Porém, a preocupação acompanhou-me desde o momento em que entrei no país até minha saída. Só respirei aliviada ao deixar a salinha de interrogatório da imigração e entrar no avião para a Europa.

As intensas medidas de segurança de Israel, por um lado, deixavam-me extremamente desconfortável. Por outro lado, viajando sozinha em uma área instável, onde há um conflito armado em andamento que pode irromper a qualquer momento e que, ademais, recebe milhares de turistas das mais diversas partes do mundo todos os dias, sentia-me um pouco mais segura ao saber que alguém estava se preocupando com a segurança. Apenas um exemplo dos muitos sentimentos e impressões contraditórios que eu iria enfrentar dali por diante.

Em meus primeiros dois dias em Tel-Aviv ainda desconhecia o território em que estava pisando. Assim, para meus anfitriões receosos, expliquei apenas que, como cristã, é importante, ao menos uma vez na vida, passar o Natal no local do nascimento de Jesus Cristo, a razão do Cristianismo.

\section{Em Belém, a cidade do Natal}

O percurso de Tel Aviv a Belém não está disponível no Google Maps, visto que a Palestina foi excluída do aplicativo. Porém, seguindo a orientação do pessoal da guest house que iria me receber, julguei relativamente fácil chegar: intercalando táxi, ônibus e metrô até o Portão de Damasco, em Jerusalém Oriental, onde peguei o último ônibus, árabe, até a Hebron Road, em Belém, e desci na última parada. Dali, caminhei por cerca de 200 metros até o Bethlehem Bible College - $\mathrm{BBC}$, minha residência para os próximos meses. Era início da tarde do dia 23 de dezembro, uma sexta-feira cheia de turistas.

O BBC é uma escola da Bíblia em língua árabe, tendo alunos palestinos, de diversos países do Oriente Médio (por videoconferência) e internacionais. É um dos principais centros de estudo de teologia palestina, que contrapõe a teologia sionista em voga no Ocidente, principalmente entre cristãos evangélicos pentecostais ${ }^{3}$, a qual entende que Israel, como povo escolhido de Deus, tem o direito irrevogável de retornar às terras dos tempos bíblicos.

Na igreja cristã ocidental sequer se imagina a existência de uma igreja cristã palestina, muito menos uma tão atuante como a que encontrei. Na década de 1990, por exemplo, o BBC envolveu-se em atividades de diálogo com representantes do

\footnotetext{
${ }^{3}$ Para aprofundamento do tema, recomendo o documentário With God on Our Side, do diretor Porter Speakman Jr. O colega Magno Paganelli escreveu uma resenha sobre o documentário, também discutindo o tema do sionismo no Cristianismo Ocidental. A resenha foi publicada na Edição 3 desta revista, em dezembro de 2014.
} 


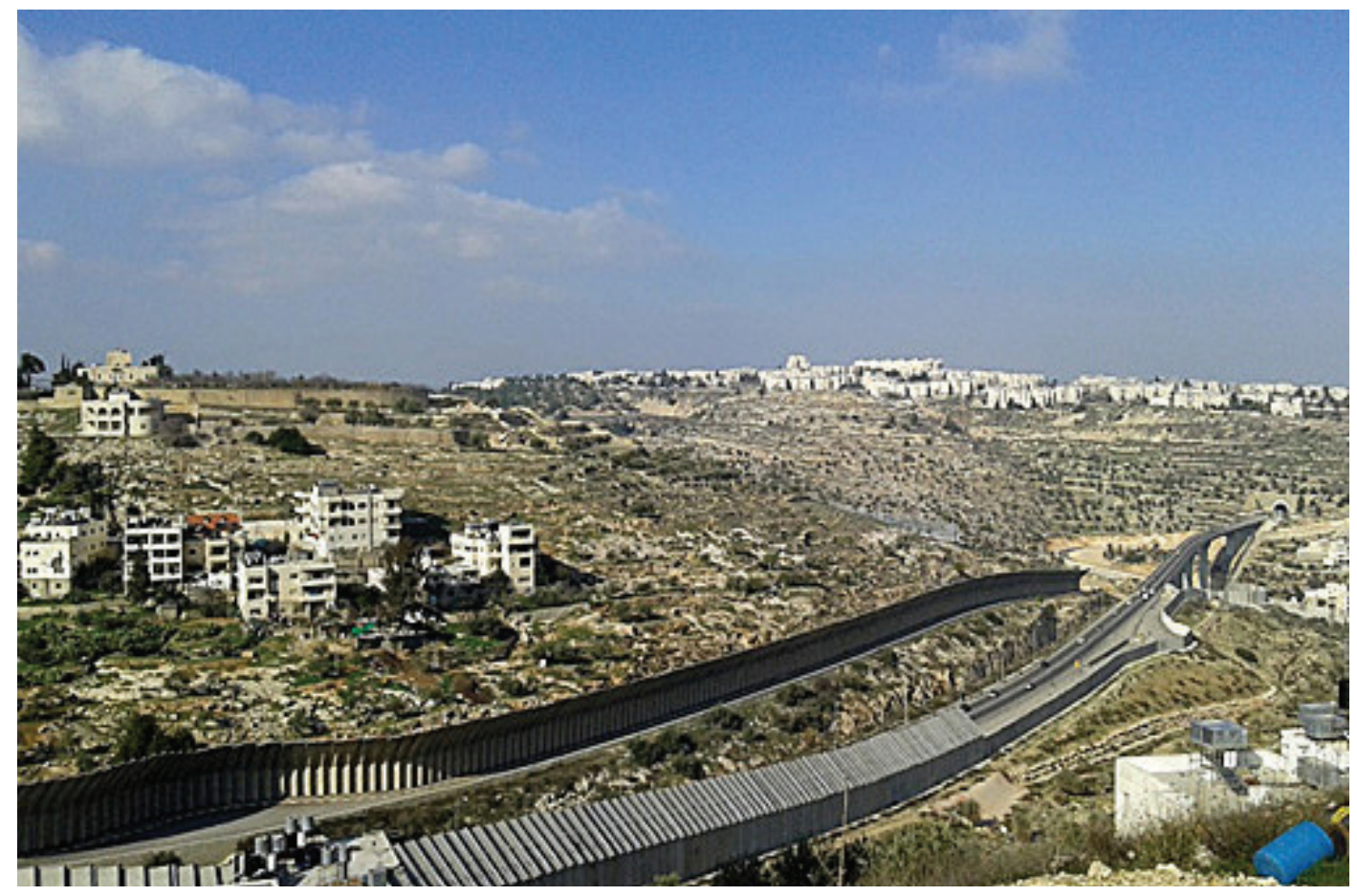

Vista a partir de Beit Jala, cidade vizinha a Belém. O Muro da Cisjordânia restringe a movimentação de palestinos e israelenses e cria um regime de segregação.

Hamas, servindo jantares em Gaza e na Cisjordânia para discutir opções pacíficas para os palestinos 4 . Atualmente, duas das principais ONGs palestinas trabalhando por paz surgiram por iniciativa de professores e pessoas relacionadas ao BBC. Musalaha ${ }^{5}$, fundado pelo árabe-israelense Salim Munayer, tem como objetivo reunir no deserto judeus, cristãos e muçulmanos de Israel e da Cisjordânia, que, enquanto viajam em camelos enfrentando os desafios do Neguev e do Sinai, encontram nos desafios de sobrevivência e cooperação uma oportunidade para conhecerem melhor o "inimigo", e, eventualmente, chegar a uma reconciliação. Holy Land Trust ${ }^{6}$, fundado por Sami Awad, sobrinho de Mubarak Awad - o Gandhi palestino, e filho de Bishara Awad, fundador do BBC, defende a resistência não violência e hoje empenha-se para criar diálogo entre palestinos e colonos judeus dos assentamentos.

O prédio do BBC está na Hebron Road, a estrada de Jerusalém até Hebron. Onde Jerusalém e Belém se encontram, o Muro da Cisjordânia foi construído, separando as duas cidades. O Muro, da Cisjordânia ou da Palestina, ou Barreira de Separação, como é chamado por Israel, começou a ser construído durante o governo de Ariel Sharon, em 2001, durante a Segunda Intifada, como medida de segurança contra os ataques terroristas constantes contra civis israelenses, e ainda não está concluído. São mais de $700 \mathrm{Km}$ de extensão, um misto de cercas físicas, barreiras eletrônicas vigiadas por câmeras, trincheiras, pontos de observação e patrulha e paredes de concreto que chegam a ter oito metros de altura em algumas partes. Uma parte dela segue a linha do Armistício de 1949, mas a maior parte foi construída adentrando até $22 \mathrm{Km}$ o território palestino.

\footnotetext{
${ }^{4}$ Ver ANDREW, B.; JANSSEN, A. Força da luz. São Paulo: Editora Vida, 2005.

${ }^{5}$ Website: $<$ https://www.musalaha.org>.

${ }^{6}$ Website: <https://holylandtrust.org>.
} 


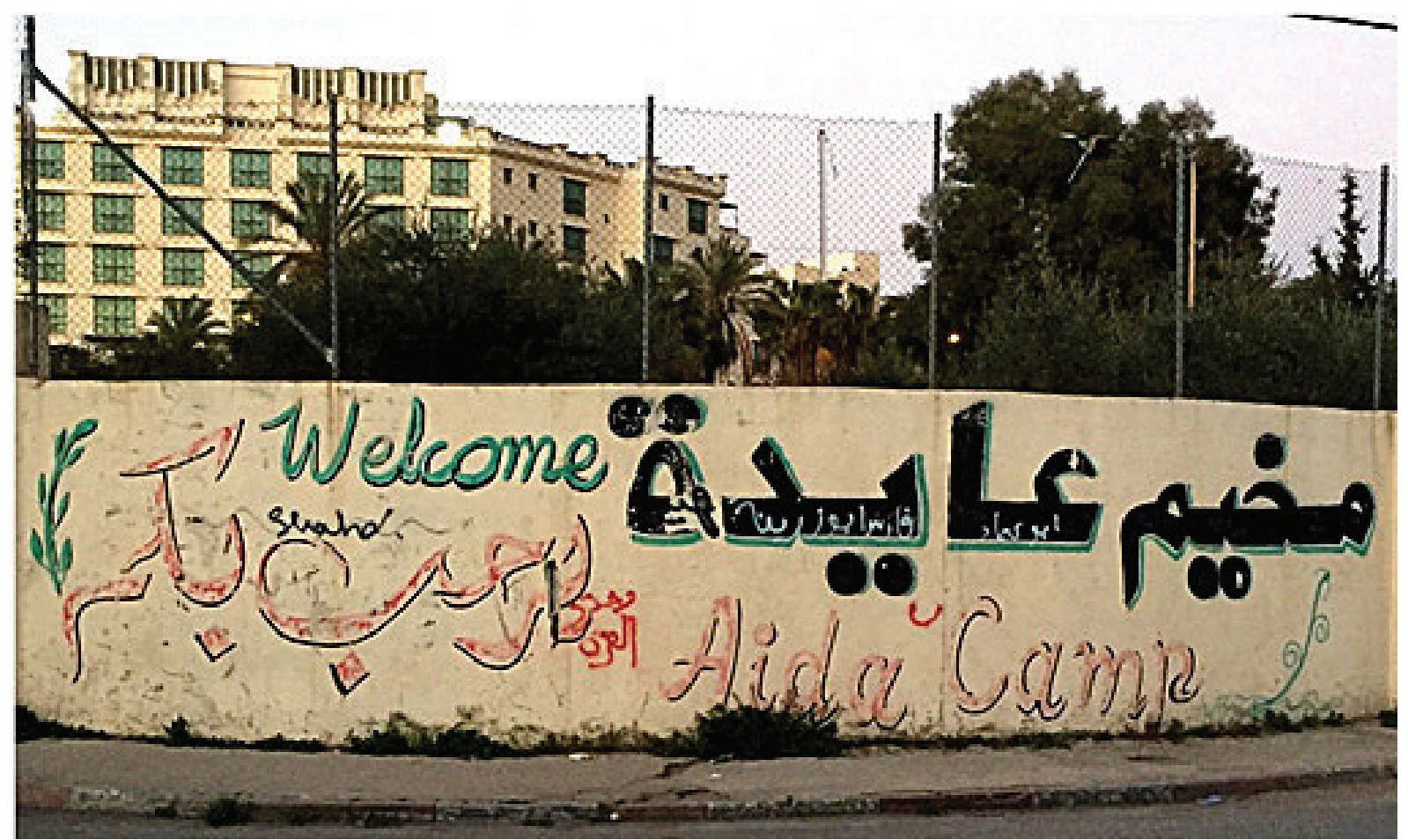

A entrada do campo de refugiados Aida, de onde era comum ouvir o som de tiros no meio da noite.

O Muro foi considerado ilegal em 2004, pelo Tribunal Internacional de Justiça, pois corta terras palestinas e isola seus moradores. Na prática, cria um regime de segregação que encerra os palestinos em bolsões populacionais e afasta as sociedades israelense e palestina, além de criar contratempos imensos para percorrer pequenas distâncias. Para passar de um lado ao outro do Muro, é preciso atravessar checkpoints, os postos de fronteira israelenses ${ }^{7}$.

Na Hebron Road, a 500 metros do BBC, fica o Checkpoint 300. Ao lado do Muro, estão os campos de refugiados palestinos Aida Camp e Al Azzar Camp, um à direta e outro à esquerda da Hebron Road. Mais adiante, na mesma rua, está o Dheisheh Refugee Camp, o maior em Belém, cujos moradores deixaram Jerusalém na guerra de 1967. O BBC está entre os campos de Aida e Al Azzar.

$\mathrm{Na}$ véspera do Natal, a cidade de Belém recebe milhares de visitantes de todas as partes do mundo. As comemorações começam na primeira semana de dezembro e vão até o final de janeiro. A programação, organizada pela administração municipal de Belém e pelo Ministério de Turismo e Antiguidades da Palestina, envolve desde os sinos das igrejas cristãs tocando todos os dias ao mesmo tempo e no mesmo horário e as ruas enfeitadas com luzes, até concertos musicais e desfiles de bandas e fanfarras nas ruas da parte velha

\footnotetext{
${ }^{7}$ Checkpoints são os postos de fronteira entre Cisjordânia e Israel e dentro da Cisjordânia. De acordo com a ONG israelense B'Tselem, que monitora as atividades de Israel nos Territórios Palestinos, em janeiro de 2017, há 98 checkpoints fixos na Cisjordânia. Além disso, na última contagem feita pela ONU em 2015, havia 361 checkpoints móveis. Há, ainda, 32 checkpoints permanentes ao longo do Muro da Palestina. Ver: <http://www.btselem.org/freedom_of_movement/ checkpoints_and_forbidden_roads>.
} 
da cidade. Foi esse clima de celebração e de hospitalidade aos visitantes que marcou minha chegada e minhas primeiras semanas.

Ficar hospedada na guest house do Bible College envolvia o risco de estar muito mais exposta à perspectiva palestina. Por outro lado, a participação do BBC no movimento pela paz proporcionou-me oportunidades e contatos que não estavam previstos na pauta inicial. Um exemplo disso foi a entrevista que realizei com o diretor de uma ONG em Gaza, ligado ao BBC. Nossa conversa foi o mais próximo que cheguei da realidade da Faixa de Gaza. Ainda, algumas das pessoas em minha lista para entrevistas tinham contato com o BBC. Certo dia, durante o almoço, um convidado importante foi apresentado. Que surpresa a minha! Era um ativista americano com quem eu tinha entrado em contato várias vezes, mas não tinha obtido resposta.

Por ser um lugar ainda pouco conhecido, optei por dar um foco maior às minhas experiências na Cisjordânia neste relato.

\section{Cotidiano em uma área de conflito}

Minha primeira impressão foi de uma Palestina em que tudo é relacionado à situação política. As marcas e a narrativa do conflito estão por toda a parte. Até mesmo nas redes públicas de wi-fi, com nomes como freedom for Palestine, end the occupation ou Palestine for Palestinians. Nas mensagens de Natal nas igrejas, a ocupação israelense foi comparada à ocupação do Império Romano, no século I d.C., e o Cristo palestino é

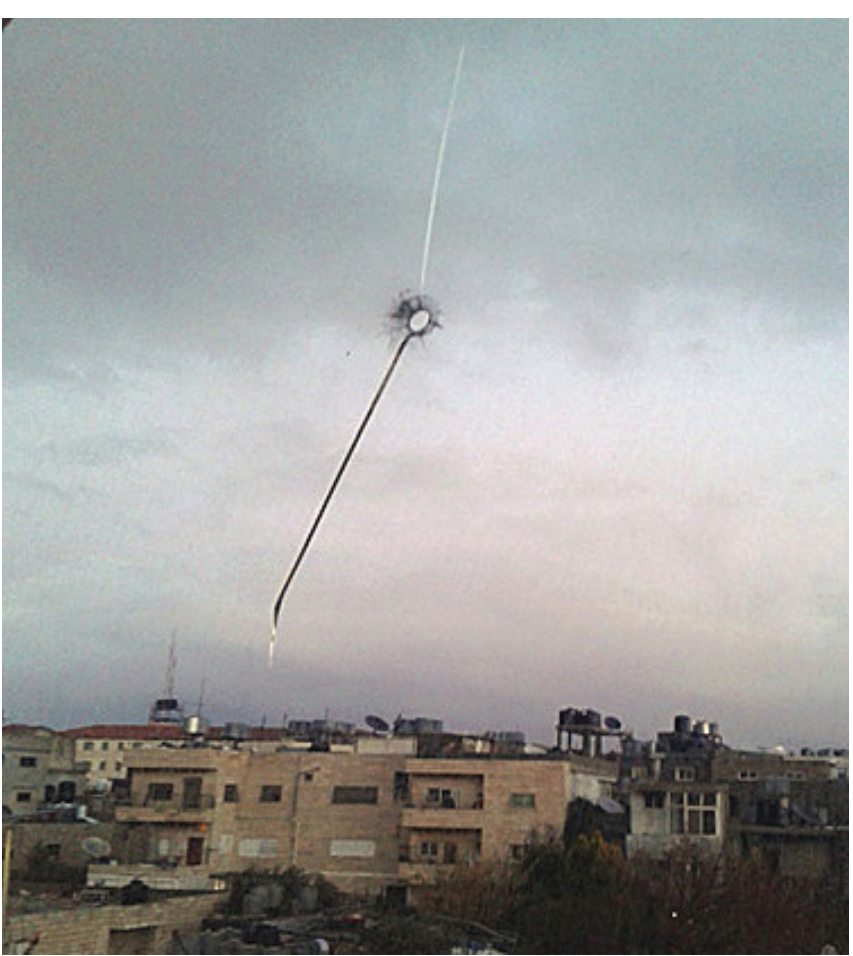

Na janela de meu quarto no BBC, a constante recordação de estar em uma área de conflito. Ao fundo, o campo de refugiados de Al Azzar. cheio de anseios por emancipação e liberdade. As conversas do dia a dia, com vizinhos, com o motorista de táxi, com o atendente da farmácia giravam em torno da questão palestina. Mesmo com os voluntários do BBC, em geral europeus ou americanos, a pauta repetia-se. Queria comentar sobre a arquitetura de um prédio e o assunto em segundos ia para as caixas d'água pretas, visíveis em todas as casas palestinas, e para a distribuição de água, controlada por Israel.

Da janela de meu quarto, podia ver o campo de refugiados Al Azzar e também o Checkpoint 300. Uma marca de bala no vidro, deixada pelos confrontos entre soldados israelenses e combatentes palestinos no que ficou 


\section{relato de campo}

conhecida como a Intifada Individual, em 2015, era minha recordação diária de estar em um local instável, em que tudo podia mudar a qualquer momento. Era comum ouvir barulho de tiros no meio da noite, vindos do campo Aida. "Nunca sabemos se é por causa da violência dentro do próprio campo ou se são confrontos com os soldados israelenses", contou-me um dos funcionários do BBC.

O Checkpoint 300 é bastante conhecido e um dos mais tumultuados na Cisjordânia. Isso porque mais de 5 mil pessoas o atravessam diariamente para trabalharem em Israel. Elas mostram sua autorização de entrada, passam por um raio-X e são revistadas. A partir das 2 horas, a fila começa a se formar e vai até o início da manhã. Para conseguir chegar ao trabalho às 7 horas, por exemplo, é preciso estar no checkpoint antes das 3 horas. Um cotidiano bastante exaustivo!

Nesse checkpoint, todas as sextas-feiras e, às vezes, também às quintas-feiras, há manifestações e protestos. Em minha primeira semana, tomava um café tranquilamente após o almoço, pensando nas entrevistas agendadas para os próximos dias, quando percebi uma movimentação na Hebron Road. Fui até a janela e vi um grande grupo descendo a rua, em direção ao Muro. Carregavam caixões cobertos com bandeiras palestinas e repetiam palavras de ordem. Desci para perguntar o que estava acontecendo e fui informada de que protestavam contra Israel, pedindo a devolução dos corpos dos palestinos mortos em combate. Algumas horas mais tarde, o protesto terminava com pedras sendo jogadas contra os soldados israelenses, os quais respondiam com bombas de gás lacrimogênio.

Nas proximidades do checkpoint, o Muro é todo pintado. Parte das pinturas é do artista de rua e ativista político britânico Banksy, o qual inaugurou em março deste ano o The Walled Off Hotel, também próximo ao Checkpoint 300. No hotel, o atrativo principal é a vista do Muro da Cisjordânia.

A cada vez que precisava cruzar esse ou outros checkpoints não podia evitar a preocupação. Primeiro, por nunca ter certeza do tempo que gastaria ali. Para evitar chegar

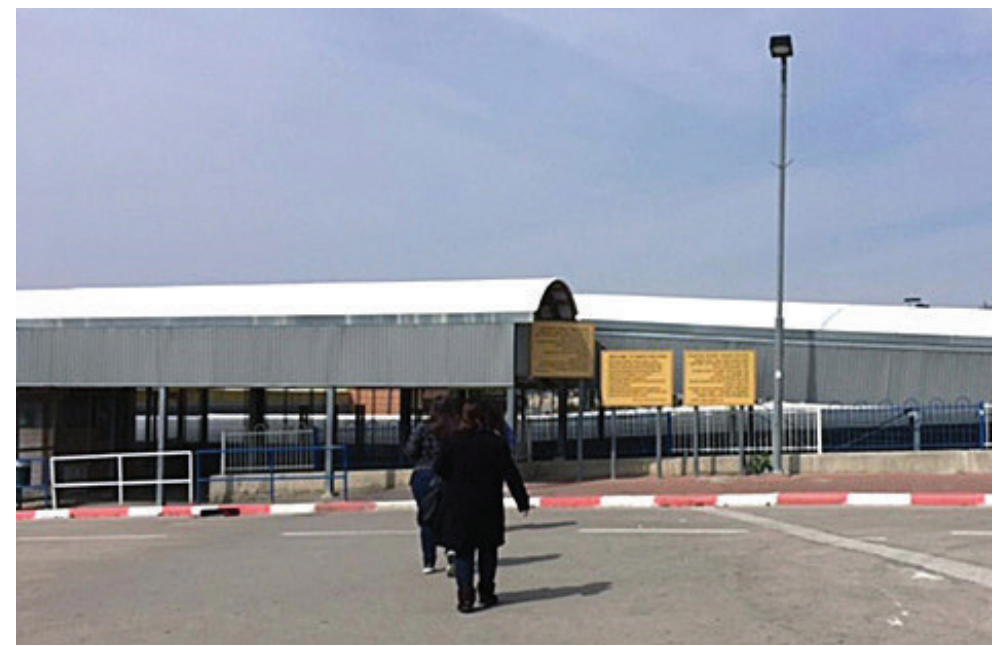

Caminhando para o Checkpoint 300 no início da tarde, quando a movimentação é menor. Por ele, passam 5 mil palestinos todos os dias para trabalharem em Israel. atrasada aos compromissos em Jerusalém, por exemplo, saía de Belém com duas a três horas de antecedência. Em alguns dias, levei mais de uma hora para atravessar a divisa. Em segundo lugar, eu estava no território inimigo. $\mathrm{Ou}$ seja, podia ser uma ameaça à segurança de Israel. Como não faço parte de uma sociedade militarizada, não podia evitar o desconforto diante dos muitos interrogatórios e desconfianças. 
Certa ocasião, viajava para o norte de Israel com amigos americanos e canadenses que fiz no BBC. Em um dos tantos checkpoint que cruzamos dentro da Cisjordânia, desconfiaram da nossa motivação para estar ali. Enquanto outras pessoas apenas mostravam passaportes e permissões, nós descemos do carro e fomos levados para uma pequena sala, aos fundos, onde passamos pelo raio-X, fomos revistados e respondemos a várias perguntas. Abrimos nossas mochilas, retiramos tudo que havia dentro. Os soldados fizeram chacotas quando explicamos que dirigíamos do Mar Morto para a região do Mar da Galileia, pois queríamos ver pontos turísticos. "Todos querem, certo? É sempre a mesma justificativa, como se tivesse algo de especial para ver lá", respondeu um dos soldados. "Citem uma única passagem bíblica sobre o Mar da Galileia e deixamos vocês irem", disseram, rindo. Depois, pediram nossos celulares e passaportes e ficamos fechados na sala, esperando, sem maiores explicações. Cerca de 40 minutos depois, devolveram os celulares. Mais tarde, os passaportes e, por fim, fomos liberados.

Conforme as semanas passavam, até mesmo em checkpoints mais tranquilos, como o de Beit Jala, cidade vizinha a Belém, os olhares eram desconfiados e não raro vinha a pergunta: “Chegou em dezembro. 0 que você ainda está fazendo aqui?”.

\section{Primeiros contatos, várias dificuldades}

Antes de embarcar para Israel, estabeleci contato com quase 40 pessoas de 20 diferentes organizações envolvidas com diálogo. Tinha entrevistas previamente agendadas, ainda que sem data e local definidos, e a esperança de seguir uma agenda relativamente organizada de três entrevistas por semana, com dias livres no final de meu período para conhecer lugares turísticos e participar de outras atividades. Contudo, pouco ocorreu como planejado.

Minha principal dificuldade foi com as noções de tempo e agenda tanto de palestinos quanto de israelenses. Contatos por e-mail não funcionavam. As respostas, quando obtidas, demoravam entre três semanas a alguns meses. 0 contato com o grupo Israel/Palestine Center for Research and Information - $\mathrm{IPCRI}^{8}$, por exemplo, um dos mais importantes grupos de diálogo desde a década de 1990 e, portanto, extremamente relevante para minha pesquisa, foi uma sequência de tentativas frustradas. Enquanto estava no Brasil, troquei e-mails com o atual co-diretor israelense, explicando que estaria em Israel por dois meses. Combinamos que escreveria novamente ao chegar. Enviei novo e-mail na primeira semana, mas não obtive resposta. Tentei ligar para todos os números de telefone disponíveis no site do IPCRI, sem sucesso. Fui atendida uma única vez. Do outro, a pessoa falava em hebraico, língua que não domino. Eu continuava repetindo "English, English, please". Por fim, desliguei o telefone e decidi ir até o endereço disponível no site. La, recebi a informação de que tal escritório não existia. Quase três meses depois, quando já estava de volta ao Brasil, recebi a resposta do co-diretor ao meu primeiro e-mail: "Que dia desta

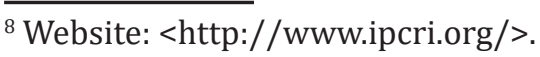




\section{relato de campo}

semana podemos nos encontrar em Jerusalém?". Infelizmente, era tarde demais para nos encontrarmos em Jerusalém!

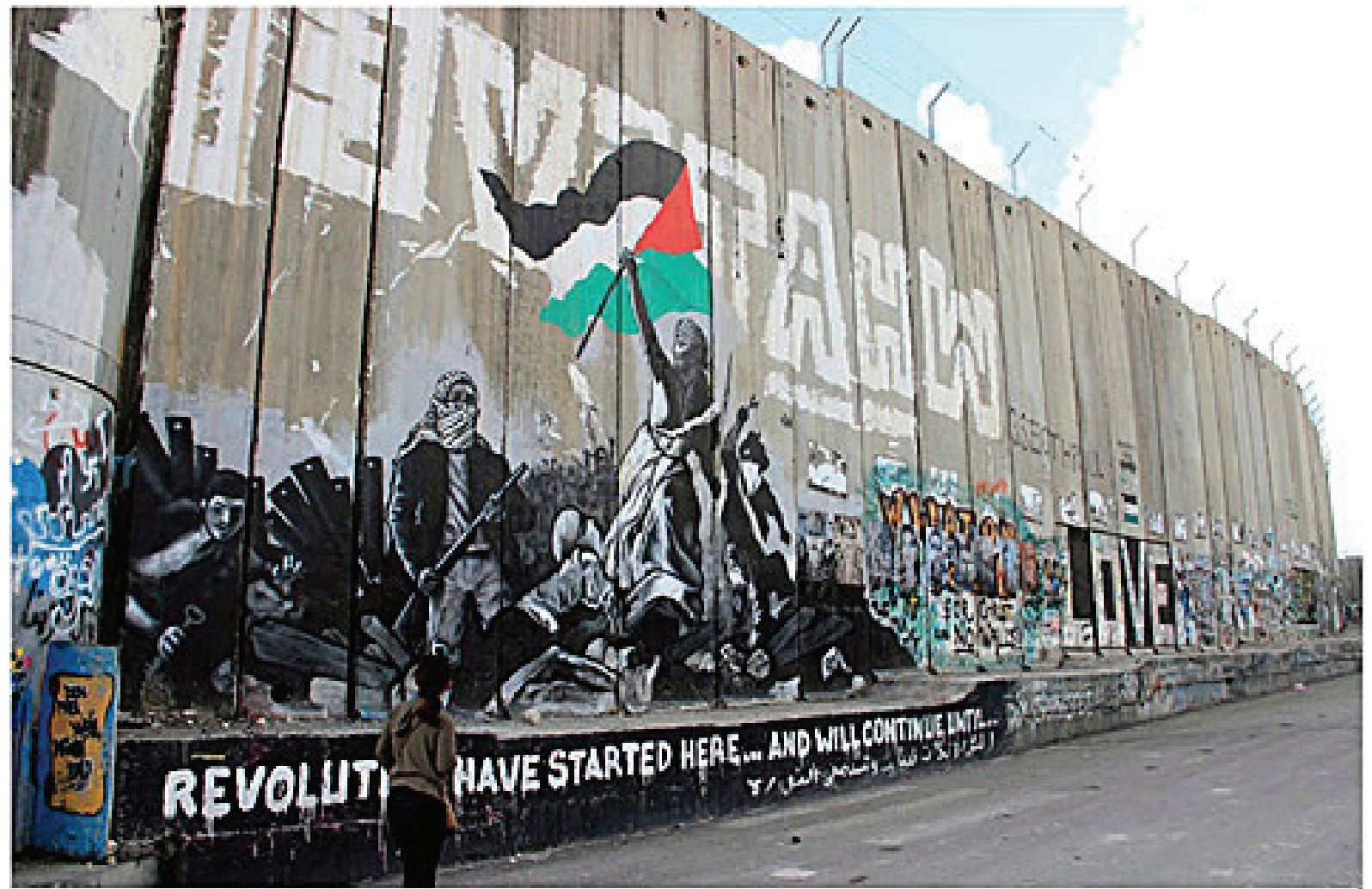

Pintura de Banksy, próxima ao Checkpoint 300.

Em outra situação, entrei em contato com o co-diretor de Combatants for Peace, grupo que reúne ex-soldados israelenses e ex-combatentes palestinos agora trabalhando juntos pela paz. Sugeri uma data e local para conversamos. Nenhuma resposta. Uma semana depois, enquanto almoçava, recebi o retorno: "Estou em Talita Kumi. Vamos conversar às 15 horas". Talita Kumi é um bairro de Beit Jala, portanto próximo de onde eu estava. Porém, onde? Respondi, solicitando o local e um telefone para contato. Outra vez, nenhuma resposta. Algumas semanas mais tarde, nos encontramos em atividades da $\mathrm{ONG}$, das quais participei como observante, e comentei sobre nossa entrevista que não aconteceu. Ele sugeriu que conversássemos na semana seguinte, em um café próximo ao Yad Vashem, memorial do Holocausto, em Jerusalém. No dia da entrevista, ligou-me alguns minutos antes, dizendo que como eu já tinha participado das atividades da ONG considerava o encontro desnecessário e estava cancelando.

Na primeira entrevista que fiz, com Hillel Shenker, co-diretor do Palestine-Israel Journal of Politicis, Economics and Culture - $\mathrm{PIJ}^{10}$, uma publicação acadêmica que conta com a participação de importantes nomes para discutir e apresentar propostas viáveis para a solução do conflito, percebi um contratempo que me acompanharia dali em diante. 0 escritório do PIJ fica em Jerusalém Oriental, em uma rua fácil de se encontrar, caminhando

\footnotetext{
${ }^{9}$ Website: <http://cfpeace.org/>.

${ }^{10}$ Website: <http://www.pij.org/index.php>.
} 
cerca de 20 minutos a partir do Portão de Damasco. Quando cheguei ao local, não havia a menor indicação de onde estava o escritório. 0 número era de um prédio antigo, com vários andares e apartamentos. Depois de alguns minutos de procura, notei uma folha de papel A4 colada em uma porta entreaberta, com pequenas letras impressas: "Israel Publications, $3^{o}$ floor". Deduzi que poderia estar relacionado ao PIJ, que eu procurava, e fui para o terceiro andar. Hillel Shenker me esperava com chá e biscoitos.

Ao visitar a ONG Kids 4 Peace $^{11}$, em uma rua sem saída e sem placas indicativas na região norte de Jerusalém, quando comentei da dificuldade que tive para encontrar o local, mesmo usando GPS, a co-diretora explicou-me, antes de começarmos a entrevista: "Somos cinco diferentes ONGs aqui de ativistas por paz, compartilhando o mesmo prédio. Você provavelmente conhece esses grupos, pois são bem importantes. Mas decidimos nos manter em low profile. Você não verá placas ou letreiros. Nem mesmo nossos vizinhos sabem que estamos aqui. A maior parte dos grupos por paz precisa fazer isso". Perguntei o porquê disso, ela quis saber para qual jornal/revista eu trabalhava. Expliquei novamente que se tratava de uma pesquisa de mestrado de uma universidade brasileira, mas mudou de assunto. Mais tarde, enquanto respondia às perguntas de minha entrevista, voltei a perguntar sobre o motivo de se manterem discretos, se poderia estar relacionado à pressão do governo israelense ao movimento pela paz. Com um discurso que me pareceu contraditório, respondeu que não enfrentavam nenhum tipo de pressão e podiam fazer suas atividades normalmente. Na realidade, sequer tinham dificuldades, como outros grupos. A prudência era apenas uma medida de proteção. "Proteção de quê?", perguntei. Proteção para que não viessem a ter dificuldades.

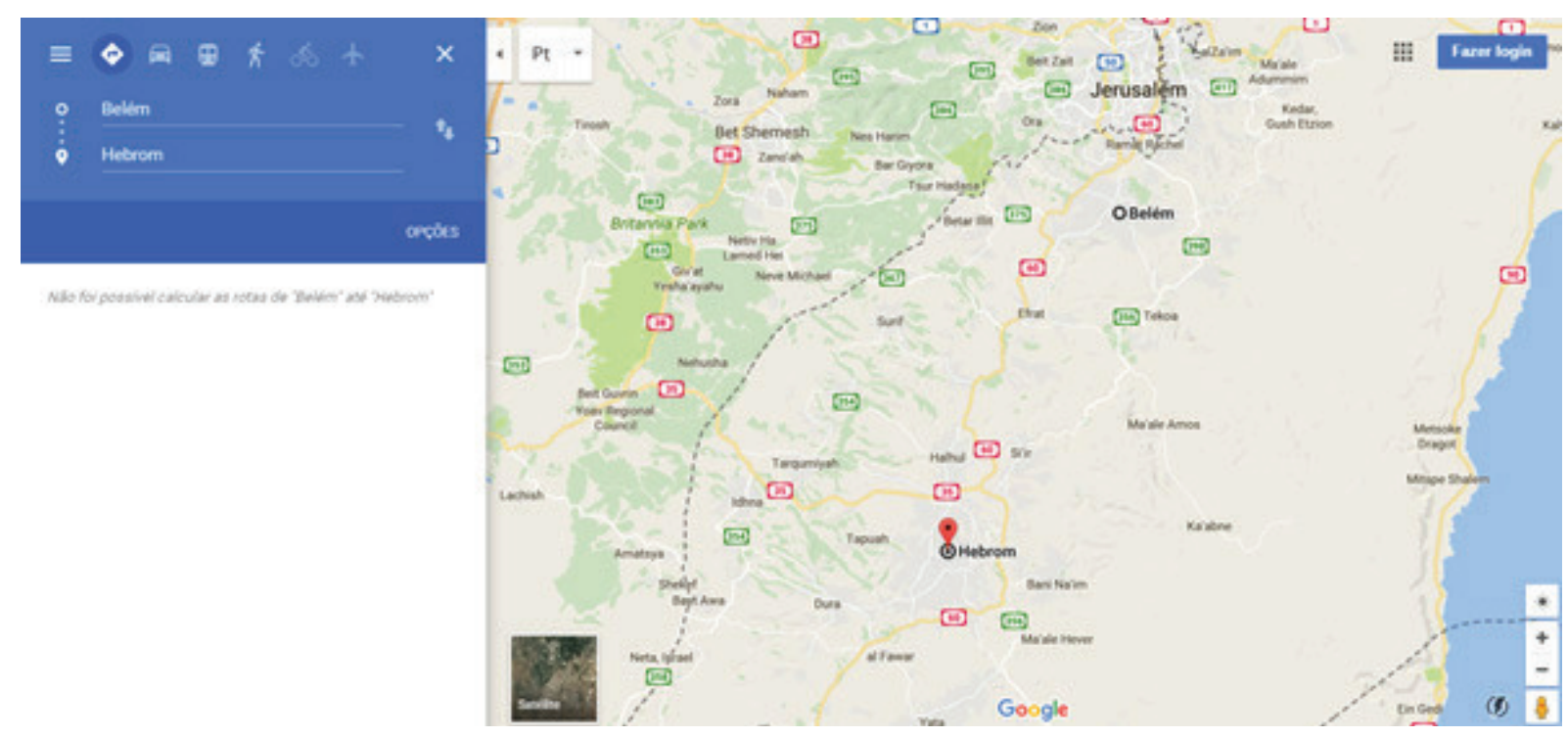

A Palestina não está incluída no Google Maps. 0 aplicativo não traça rotas dentro da Cisjordânia.

Na Cisjordânia, a discrição dos grupos e os escritórios praticamente escondidos vinha com ainda outros contratempos: o Google Maps e outros aplicativos de localização não funcionam na Palestina; além disso, o inglês não é entendido pela maior parte da

\footnotetext{
${ }^{11}$ Website: <http://www.k4p.org/>.
} 


\section{relato de campo}

população. Ao visitar o escritório de The Parents Circle Families Forum - PCFF ${ }^{12}$, uma das mais impressionantes organizações que visitei, a qual promove a reconciliação entre famílias israelenses e palestinas que perderam entes queridos no conflito, achei impossível encontrar o local indicado por Rami Elhanan, o co-diretor israelense. Decidi pedir ajuda à atendente da biblioteca do BBC, Hala Doqmaq, pois sabia que também mora em Beit Jala, local do escritório. Ela olhou para o mapa, mas não conseguiu identificar o local. Ligou para o escritório. Após alguns minutos de conversa em árabe, desligou e explicou-me que se tratava do prédio onde residem seus pais. Porém, duvidou da existência de um escritório ali, pois viveu boa parte de sua vida no mesmo endereço e nunca tinha ouvido falar do PCFF.

Hala deu-me orientação de como chegar até lá de ônibus. Para ajudar, escreveu em árabe em um pequeno papel em qual ponto deveria descer. Entreguei o papel para o motorista do ônibus, mas ele não tinha certeza sobre o ponto. Então, saí perguntando aos passageiros, por meio de gestos e mostrando o papel com o endereço. Um simpático senhor indicou o lugar. Chegando ali, não encontrei as referências dadas por Hala. Era o ponto errado. Andei por uns 30 minutos, seguindo o percurso do ônibus e decidi voltar ao mapa que Rami tinha me enviado por e-mail. A rua indicada por ele por e-mail era Nuzha Street. Parecia simples no mapa, só seguir a rua principal. Contudo, apesar de no mapa estar destacada, não se diferenciava das outras na realidade. Além disso, a cada quadra, a rua principal mudava de nome. Como saber onde estava? Resolvi pedir informações a alguns moradores locais. Com sorte, alguém entenderia inglês. Ninguém conhecia Nuzha Street. Andei por mais alguns minutos, na mesma rua, decidi ligar para Rami e dizer onde estava. Quando ele atendeu, ouvi sua voz muito próxima. Olhei para cima e estava na janela do prédio à minha frente.

\section{Hospitalidade palestina: uma brasileira entre árabes}

Os palestinos, como os brasileiros, são considerados hospitaleiros e simpáticos. Em geral, fazem um grande esforço enorme para honrarem essa reputação. Aliás, as identificações com o Brasil não param por aí. A seleção de futebol brasileira é amada na Palestina e, ao mencionar que era do Brasil, podia preparar-me para uma conversa sobre Neymar ou Ronaldinho. Durante a Copa do Mundo de 2014, a final entre Alemanha e Brasil foi projetada no Muro, perto do Checkpoint 300, onde centenas de pessoas se reuniram para assistir ao jogo. Após a derrota do Brasil, a cidade de Belém experimentou um tipo de luto, imagino que não tão diferente do que vimos por aqui.

Certa manhã, eu caminhava até o Checkpoint para encontrar um amigo israelense do outro lado. Estava bastante adiantada, mas não sabia quanto tempo iria gastar nos corredores, raio-X e interrogatório, então, precisava apressar-me. Sentado em frente ao Muro, um jovem palestino abordou-me, chamando-me de "Brasil" e dizendo: "Welcome

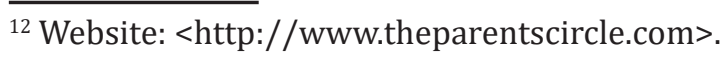


Brazil, welcome to Palestine! Eu conheço você. Está hospedada no BBC. Bem-vinda, bemvinda!". Parei, conversamos sobre trivialidades e logo segui em frente. Se um estranho afirmasse conhecer-me em qualquer outro lugar, ficaria receosa. Mas não ali.

Na segunda semana em Belém, quando boa parte dos turistas já tinha deixado a cidade, saí para conhecer sozinha a região da Manger Square. Na Basílica da Natividade, um policial aproximou-se e se apresentou. Encantado por eu ser brasileira (tendo, portanto, grandes chances de conhecer Neymar!), ofereceu-se para mostrar-me o lugar. Após contar-me a história da igreja, Sami afastou turistas e parou filas para que pudesse ter a minha foto exclusiva no local do nascimento. “Quem é ela?", perguntavam alguns turistas. "Ela está comigo", respondia Sami. Depois das fotos, ofereceu-me café e saímos para a rua, pois, como bom muçulmano, disse-me, também queria contar sobre a Mesquita de Omar, do outro lado da praça. Na rua, um carro de polícia aproximou-se. Sami fez sinal para que parassem. Cinco policiais muito armados olharam para nós de dentro do veículo, enquanto eu era apresentada. A reação diante do fato de ser brasileira não foi surpresa: "Brazil! Neymar! Welcome!". Os policiais garantiram que cuidariam pessoalmente de minha segurança enquanto estivesse em Belém. Sami entregou-me seu cartão pessoal e listou o nome dos policiais, a quem eu deveria procurar caso qualquer pessoa me tratasse de forma diferente da que ele e seus amigos me haviam tratado. "O nome disso é hospitalidade palestina", anunciou, antes de nos despedirmos.

A única reação diferente que recebi ao dizer que era do Brasil foi de Ahmad Amro, dono de uma loja de souvenir. "Brasil? Uau, então você deve estar muito feliz aqui na Palestina. Imagino que deve ser difícil viver no Brasil, um lugar tão perigoso, com tanta violência, tão pobre. Bem-vinda a Belém! Aqui somos muito tranquilos, todos se conhecem e não tem perigos como no Brasil! Você vai querer ficar para sempre!". Confesso que ri de sua ideia sobre o Brasil. Mas, afinal, todos temos nossos estereótipos sobre este ou aquele lugar. Mais tarde, ri ainda mais das histórias que ouvi sobre Cisjordânia ser praticamente uma selva, um lugar remoto e em guerra, ao qual eu não sobreviveria.

Meu novo amigo estava certo: em pouco tempo eu já me sentia em segurança e à vontade em Belém. O barulho, a agitação das ruas e a presença, que me causaram estranhamento nos primeiros dias, sem demora tornaram-se parte do dia a dia. Conquanto não olhasse para o gigantesco Muro, lembrando-me de que estava "presa do outro lado", tudo ia mais do que bem. Estava na hora de explorar outras cidades da Cisjordânia.

\section{Hebron, microcosmo de uma guerra histórica}

Dos locais que visitei na Palestina, Hebron foi o que chamou mais minha atenção. Descemos do ônibus que nos levou de Belém e experimentei a sensação de ser uma mulher ocidental no mundo muçulmano de forma que ainda não havia experimentado. Em Belém, a presença de estrangeiros é bastante comum. Ou seja, dá para sobreviver falando inglês e não é incomum ver grandes grupos de turistas visitando um lugar ou outro. Ainda, com 
uma população cristã considerável (20\% dos cidadãos de Belém são cristãos; em Beit Sahour, Beit Jala e Belém concentra-se mais de $90 \%$ da população cristã da Cisjordânia) e com muçulmanos ocidentalizados, as características culturais e religiosas muçulmanas são bastante amenizadas. É comum, por exemplo, ver mulheres andando sozinhas, usando roupas ocidentais e sem hijab. Pela mistura de etnias na cidade, eu poderia passar facilmente por palestina.

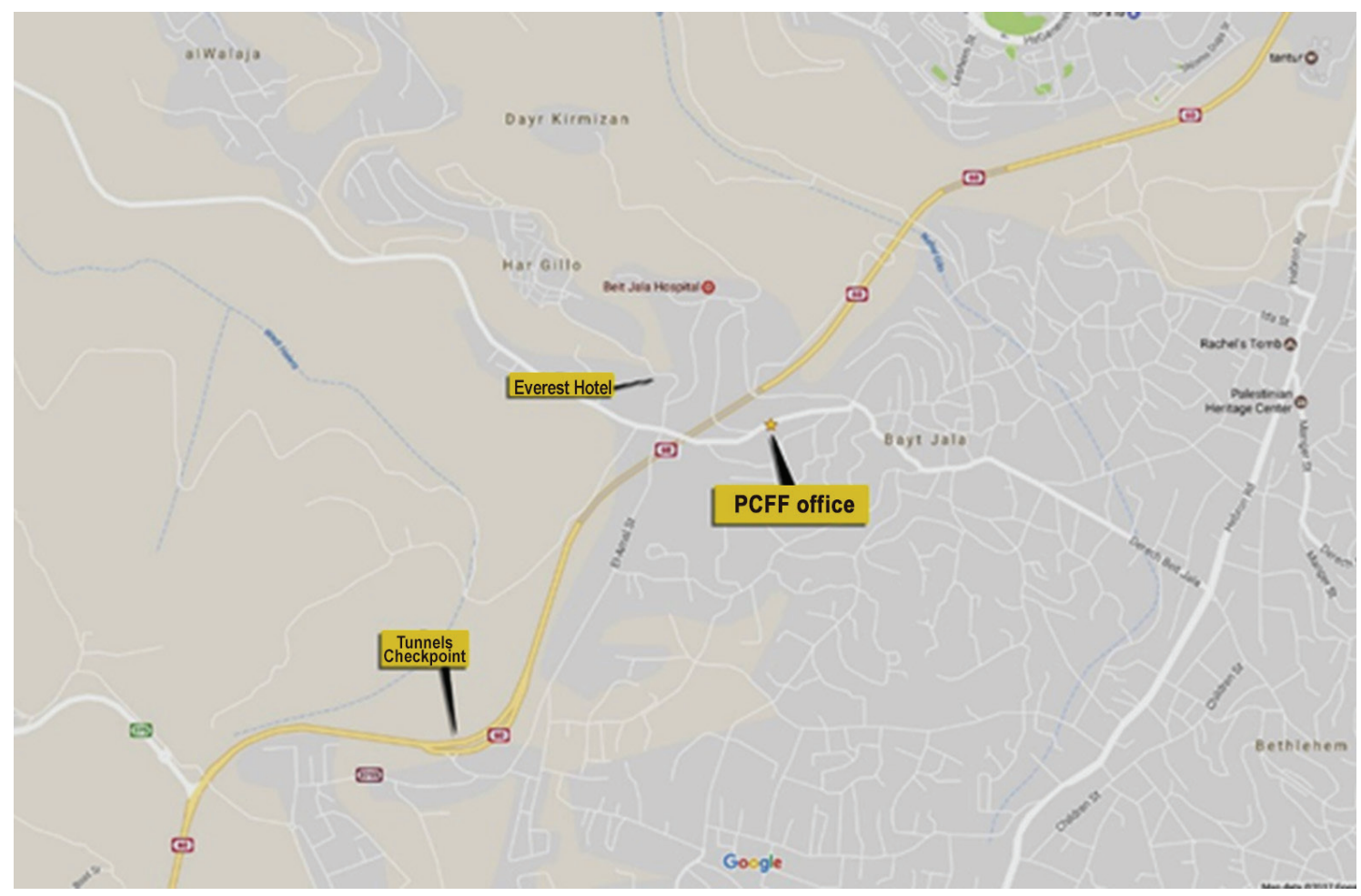

O mapa enviado por Rami Elhanan, indicando o escritório de Parents Circle, em Beit Jala. Nem mesmo os moradores locais sabiam que sua rua leva o nome de Nuzha Street.

Em Hebron, por outro lado, a presença muçulmana é bem mais marcante. Não vi mulheres desacompanhadas, todas usavam compridos vestidos e hijab, quando não burca. Apesar de não ter ido sozinha, sentia-me observada constantemente, uma presença incomum. Ao visitar a Mesquita Ibrahimi, precisei vestir uma capa azul, cobrindo da cabeça até os pés. Na segunda visita ao local, um grupo de mulheres muçulmanas quis tirar uma foto comigo. Riam baixinho de mim e da amiga que estava comigo. Pareceu-me a risada de alguém que estava vendo algo que nunca viu antes. 0 que havia chamado tanta a atenção delas sobre nós? Nossas roupas? 0 cabelo? Estarmos sozinhas? Não entendi completamente a situação.

Hebron é um microcosmo do conflito israelo-palestino e da ocupação de Israel na Cisjordânia. Se em Belém, Jerusalém, Jericó, Nazaré ou Ramalá é possível até deixar de lado a disputa entre os dois povos e ser um simples turista, em Hebron isso é improvável. A cidade fica ao sul da Cisjordânia. Ali, segundo a tradição, está sepultada a família patriarcal - Abraão e Sara, Isaque e Rebeca, Jacó e Lia, importante tanto para judeus quanto para muçulmanos e cristãos. 0 local é palco de disputas e dos mais violentos confrontos. 


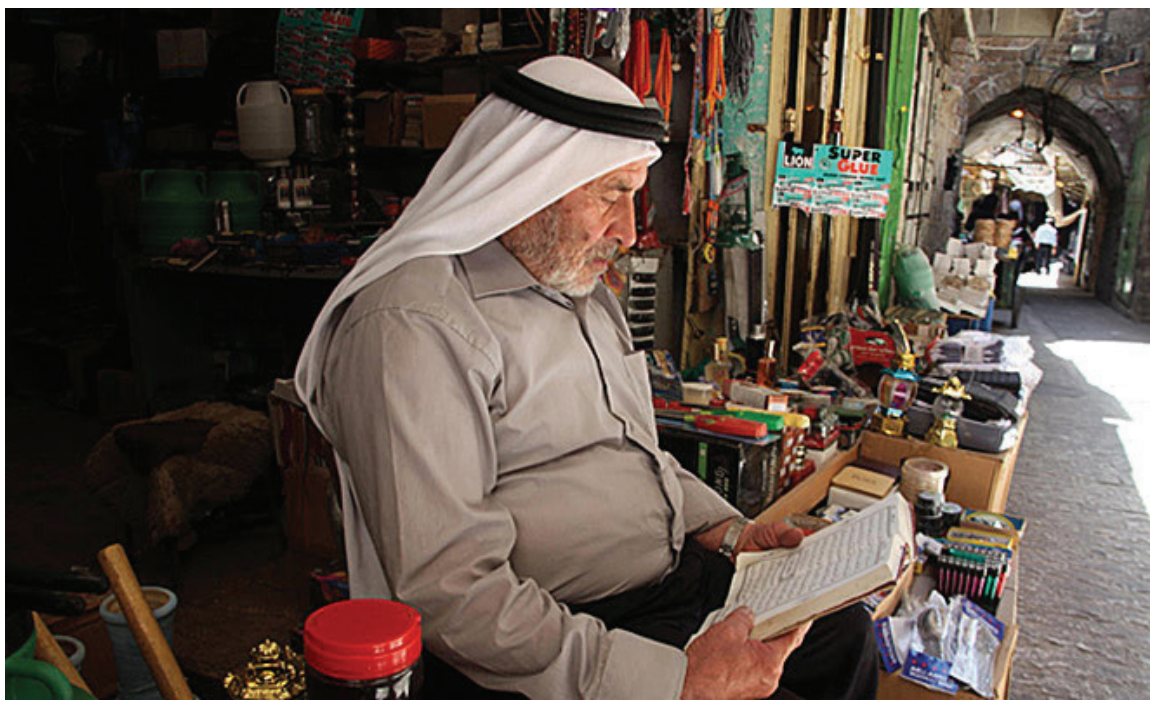

No mercado árabe de Hebron: desci do ônibus e estava totalmente inserida do mundo muçulmano. $\mathrm{Na}$ foto, homem lê Alcorão enquanto espera por clientes em sua loja.

Houve um acordo específico para dividir Hebron em 1997, definindo duas áreas na cidade, a H-1 e H-2. A área H-1 é administrada pelos palestinos, compreendendo cerca de 80\% de Hebron. A área H-2 é ocupada por Israel, e abrange a parte velha da cidade e o bairro judaico, ou, dependendo da fonte que nos informa, assentamento de colonos israelenses. $\mathrm{Na}$ área H-2 vivem cerca de 40 mil palestinos, mais 850 israelenses. Entre 1.500 e 2 mil soldados estão permanentemente ali, para garantir a segurança desses israelenses.

Andando pelas ruas tanto da área H-1 quanto da H-2, é possível distinguir claramente quais construções são habitadas por israelenses e quais por palestinos. As cercas e arames

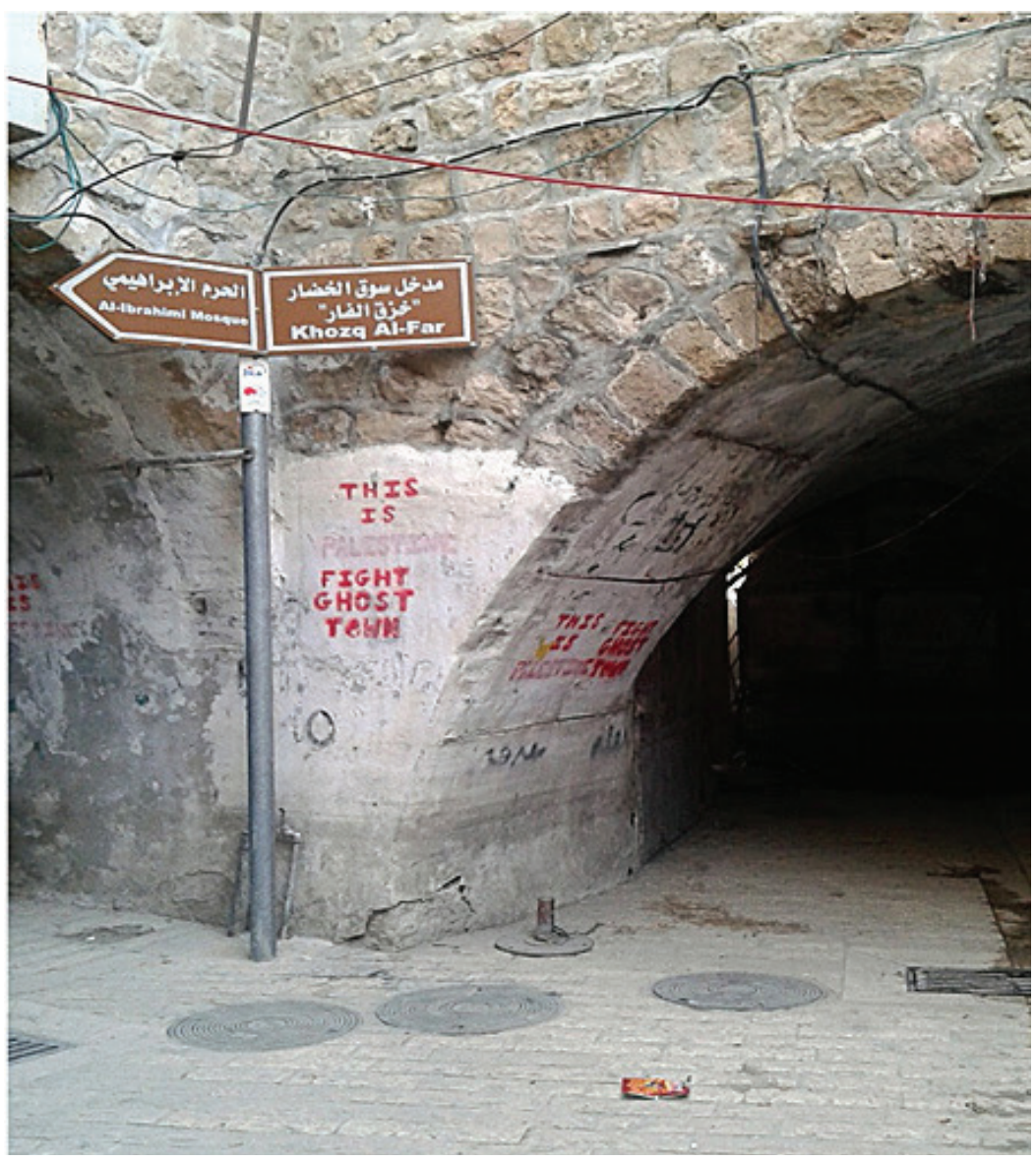
dividem as vizinhanças, as bandeiras de Israel ou da Palestina agitam-se nas janelas. Em algumas ruas na cidade velha, em que os moradores dos andares superiores dos prédios são israelenses e os dos andares inferiores são palestinos - ou viceversa - é comum ver redes de proteção estendidas de um lado ao outro da rua. 0 motivo? Os moradores dos

Cidade fantasma: após cruzar o mercado árabe na área H-1, em direção à Mesquita de Ibrahimi, uma parte das lojas e casas foram abandonadas devido aos confrontos violentos entre os moradores judeus e muçulmanos. 
andares superiores descartam o lixo pela janela - lixo orgânico, roupas e calçados velhos e até mesmo pequenos móveis podem ser vistos suspensos nas redes - para atingir os vizinhos que estão embaixo.

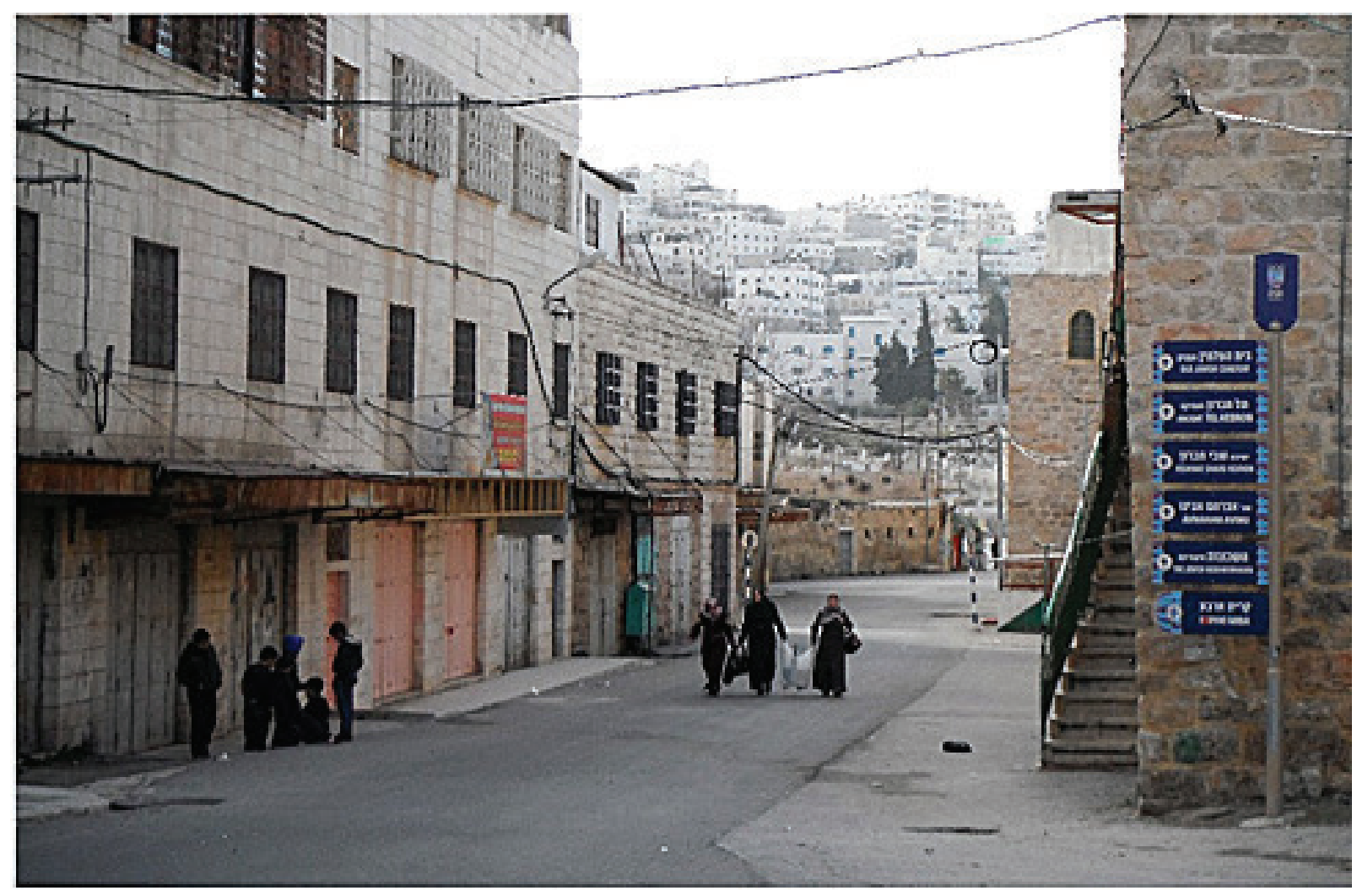

Mulheres e crianças andam pelas ruas da cidade fantasma, na área H-1, próximo à Sinagoga Ma’Arat HaMachpela

O local em que fica o túmulo dos patriarcas está dividido praticamente ao meio. De um lado, a Mesquita de Ibrahim, com acesso aos túmulos de Isaque e Rebeca, Abraão e Sara. De outro, a Sinagoga Ma'Arat HaMachpela, com os túmulos de Jacó e Lia. Muros e cercas e um checkpoint separam a entrada da Mesquita, na área H-1, da entrada da Sinagoga, na área H-2.

Tanto da Sinagoga quanto da Mesquita é possível ver o túmulo de Abraão, em uma sala cujo acesso é proibido, mas com janelas com grades dos dois lados. Para evitar tiroteios entre os inimigos declarados, um vidro à prova de balas ao lado do túmulo de Abraão bloqueia a visão entre as duas janelas.

Minha sensação, após visitar a Sinagoga e a Mesquita, foi de estar testemunhando uma briga de família, de dois irmãos ou primos que compartilham a mesma história familiar, mas que hoje, por um motivo ou outro, não conseguem mais conviver. É claro, não se pode reduzir o conflito dessa forma, com todos os níveis de violência e injustiças cometidas e sofridas pelos dois lados. Contudo, se Hebron é um microcosmo do conflito, conhecer o túmulo de Abraão, para mim, foi como vislumbrar um microcosmo do microcosmo. 
Na primeira vez em que estive em Hebron, ao sair da Sinagoga Ma'Arat HaMachpela, parei para pegar alguns folhetos explicativos distribuídos por um judeu britânico. Daniel, após entregar vários folhetos, em geral em defesa da presença israelense no local e da importância do Túmulo dos Patriarcas no judaísmo, contou-nos sua história. Sua mãe fugiu da Europa durante a Segunda Guerra Mundial para viver no que mais tarde seria o Estado de Israel. Só assim sobreviveu ao Holocausto. Só assim Daniel nasceu e pode crescer sem ser perseguido por ser judeu. Já adulto, foi viver na Inglaterra, portanto também tem cidadania britânica. Após os 50 anos, decidiu voltar para Israel e lutar pela manutenção do Estado e pela existência pacífica dos judeus nesta terra. Carregava uma arma na cintura. Explicou que já tinha enfrentado diversas situações tensas em Hebron. Agora trabalhava sempre próximo aos soldados.

Nos despedimos de Daniel, agradecendo a cordialidade conosco e decidimos andar pelas ruas quase desertas da área H-2. Isso porque nos arredores do Túmulo dos Patriarcas, tanto na área $\mathrm{H}-1$ quanto na $\mathrm{H}-2$, as lojas foram fechadas e as casas abandonadas, por ser uma região de muitos confrontos. 0 local é chamado de Cidade Fantasma. Há poucos moradores, os turistas são ainda mais raros.

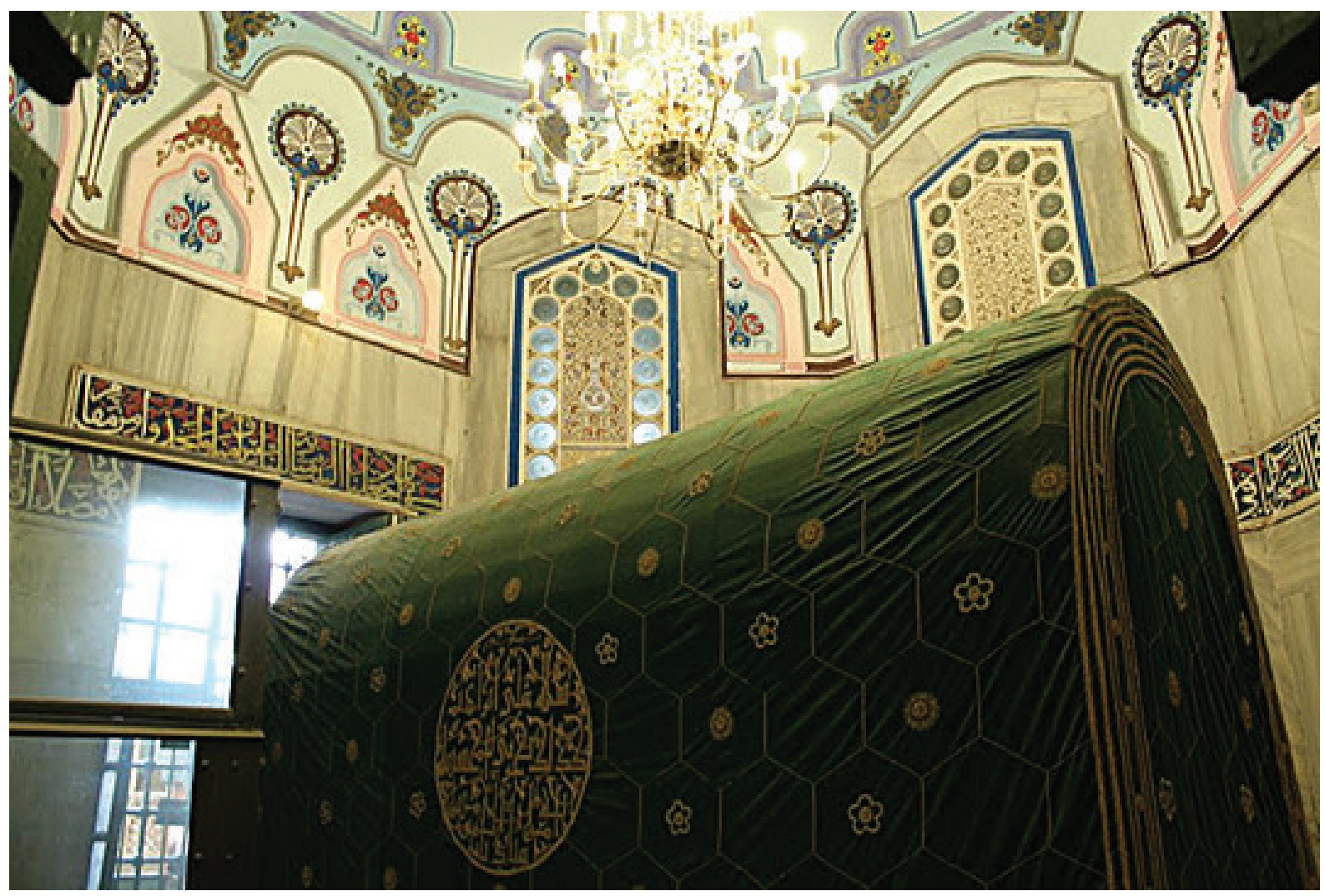

Na parte central do Túmulo dos Patriarcas, o memorial de Abraão pode ser visto tanto da Mesquita quando da Sinagoga. Para evitar tiroteios, o vidro à prova de balas limita a visão do outro lado.

Líamos um letreiro sobre uma passagem bíblica relacionada ao local em que estávamos quando uma família muçulmana, limpando e separando folhas de chá na área 


\section{relato de campo}

externa de sua casa, convidou-nos para sentar e tomar um café árabe. Enquanto meus amigos ficaram por ali, brincando com as crianças e tentando comunicar-se com a família, que falava apenas em árabe, afastei-me um pouco, para um cemitério projetando-se na encosta à nossa esquerda. Andei entre as sepulturas, tirando fotos e tentando imaginar as histórias daquelas pessoas. Quando me dei conta, cerca de 15 soldados israelenses desciam pela encosta, armas em punho, no que pareceu-me uma perseguição, ou um cerco. Senti-me transportada para dentro da cena de um filme e, por alguns segundos, duvidei de se tratar de uma situação real. Vinham em minha direção. Fiquei paralisada com todas aquelas armas apontadas para mim. Ouvi ao longe meus amigos chamando, pois também viram os soldados. Dei alguns passos para trás, devagar, na esperança de ter sido identificada como quem realmente era: uma turista no lugar errado e na hora errada.

Ao retornar à casa da família palestina, eles riam da situação como se meu estranhamento fosse absurdo. Falavam em coro e apontavam para mim, rindo: "Terrorist!", uma das poucas palavras que conheciam em inglês. Deduzi que os soldados buscavam suspeitos de terrorismo. Nesse clima tenso, mas descontraído, entramos na casa para o chá, seguido de um café árabe. Depois, nos mostraram cada cômodo, ofereceram doces, mostraram fotos e vídeos em seus celulares de outros membros da família. Apesar de nenhum dos grupos falar a língua do outro, nossa visita durou mais de uma hora. Nos despedimos no final da tarde, prometendo voltar na semana seguinte.

\section{Desestruturando a (aparente) normalidade}

Na primeira semana de janeiro, o filme Disturbing the Peace ${ }^{13}$ foi exibido nas principais cidades de Israel e da Cisjordânia, em seu lançamento. Produzido pelo americano Stephen Apkon, o documentário segue a história de seis pessoas, ativistas do grupo Combatants for Peace - CFP, três ex-soldados israelenses e três ex-combatentes palestinos, que passaram anos presos em Israel. Após terem contato com o outro lado, esses ex-combatentes entraram em uma jornada de transformação pessoal em que sua visão anterior sobre o conflito foi mudada e passou a incluir a perspectiva do outro. Então, decidiram se reunir e criaram a organização Combatants for Peace.

Em um sábado à noite, fui à exibição do filme em Belém, evento promovido pela ONG Holy Land Trust, juntamente com CFP. 0 público era majoritariamente de jovens turistas em caravanas. Após a exibição, os personagens do filme, bem como produtor e diretores, responderam perguntas. Membros ativos de Combatants for Peace contaram como viviam em uma realidade diferente há 30 anos, quando as sociedades israelense e palestina estavam muito mais próximas e havia um incentivo por parte de todas as instituições para que se conhecesse e entendesse a cultura do outro. Em meio às perguntas, um jovem levantou-se e apresentou-se como sendo um judeu que vive em um assentamento israelense na Cisjordânia e que ouviu desde a infância sobre os perigos de se relacionar

\footnotetext{
${ }^{13}$ Website do filme: <http://disturbingthepeacefilm.com>.
} 


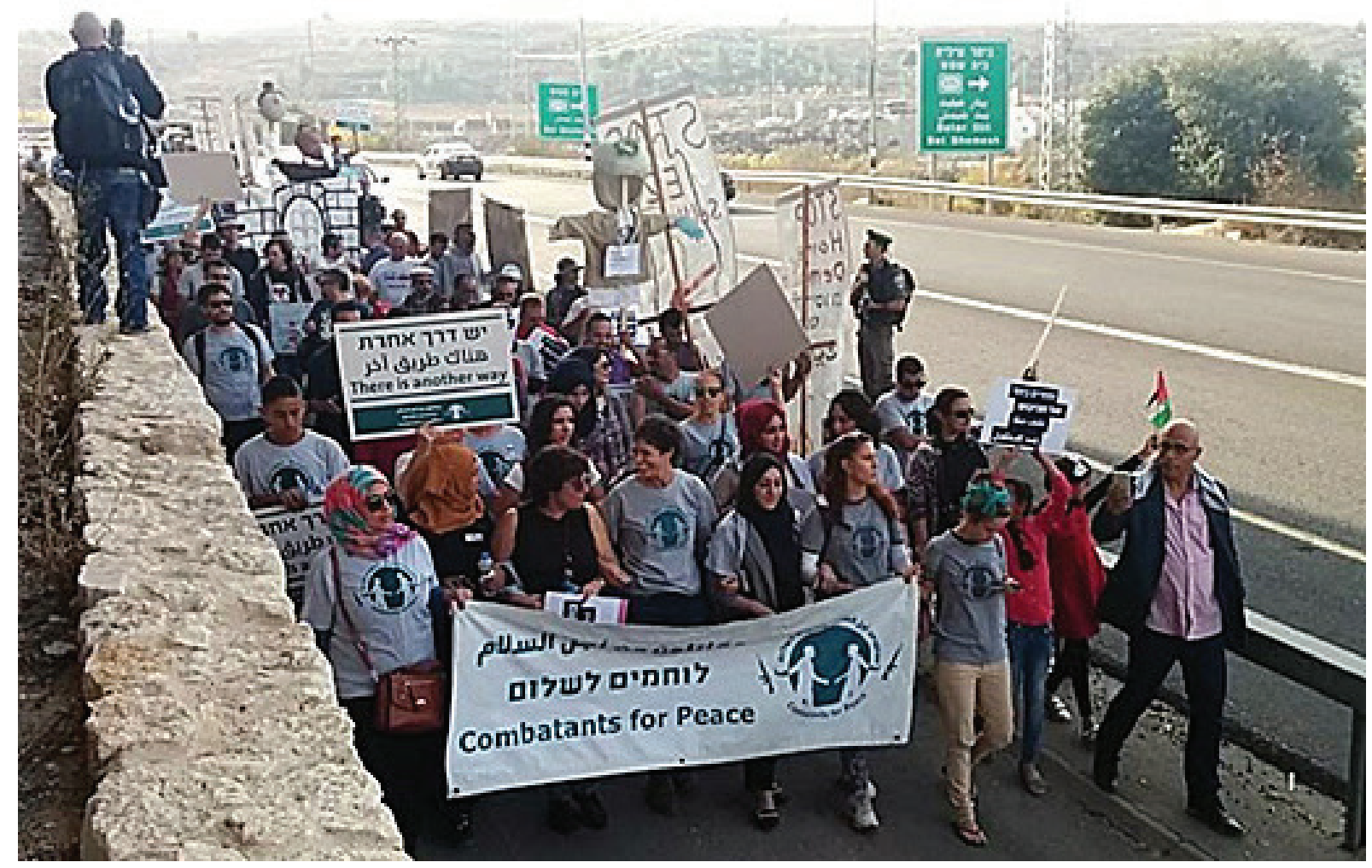

Israelenses e palestinos, ex-combatentes, em protesto contra a ocupação israelense na Cisjordânia.

com palestinos e do risco à sua vida caso tentasse entrar em Belém. "Estou aqui há mais de cinco horas e não senti qualquer ameaça. Muito pelo contrário. Até fiz amigos!”.

De fato, as barreiras físicas e psicológicas são um dos maiores desafios àqueles que querem se reunir para dialogar. As duas sociedades que costumavam interagir regularmente são, nos últimos 15 anos, cada vez mais separadas. É normal encontrar israelenses que nunca conheceram um palestino ou que não estiveram na Cisjordânia nos últimos 20 anos. Também é normal conhecer palestinos que regularmente vão para Jerusalém Oriental ou vivem ao lado de assentamentos, nos territórios ocupados, mas nunca conversaram com israelenses em toda sua vida.

Em outra ocasião, uma integrante de CFP relatou-me:

\begin{abstract}
Mesmo nossa tribo (a esquerda) está vivendo em uma bolha quando se trata da Palestina. Costumávamos ir às ruas e realizar essas demonstrações gigantes. Agora nos escondemos em nossas casas e tentamos viver uma vida tão normal quanto possível. Temos muito medo de fazer qualquer coisa. Vivemos longe das discussões políticas, longe dos problemas do outro lado do muro. Na maioria das vezes, até esquecemos que há uma muralha nos separando.
\end{abstract}

Esta separação social e psicológica é intensificada pelo Muro da Cisjordânia, cuja construção criou um sistema de apartheid que não só afasta as sociedades, mas também as despolitiza, tornando-as alheias à própria realidade.

Em meu contato com Combatants for Peace, um dos ativistas ofereceu-se para ajudar com minha pesquisa e responder às perguntas que tivesse, uma vez que estava 


\section{relato de campo}

tendo dificuldade para ter resposta dos diretores da ONG. Boris Lederman é brasileiro, nascido em São Paulo. Sua família, judia, fugiu da Europa durante o Holocausto e viveu em diversos lugares da América Latina até estabelecer-se na capital paulista. Boris apresentase como sendo israelense-brasileiro, de esquerda e amante de capoeira. No Brasil, lutou contra a Ditadura Militar e, por medo de sofrer retaliações por suas atividades políticas, decidiu mudar-se para Israel com a esposa, onde passaram a viver em um kibutz perto de Haifa. Serviu ao exército israelense dos 20 aos 50 anos, participando de três guerras e diversas atividades militares. Hoje está aposentado.

A amizade com Boris foi um achado e um elemento crucial para minha pesquisa. Como estava passando a maior parte do meu tempo em Belém, convivendo com palestinos, ouvindo e vendo a perspectiva palestina, temia não conseguir compreender o que está do "outro lado" do Muro. Com Boris, participei de atividades de CFP e podia sempre recorrer a ele (e, o melhor, em português!) para esclarecer questões que não entendia completamente, seja sobre o conflito ou sobre a sociedade israelense.

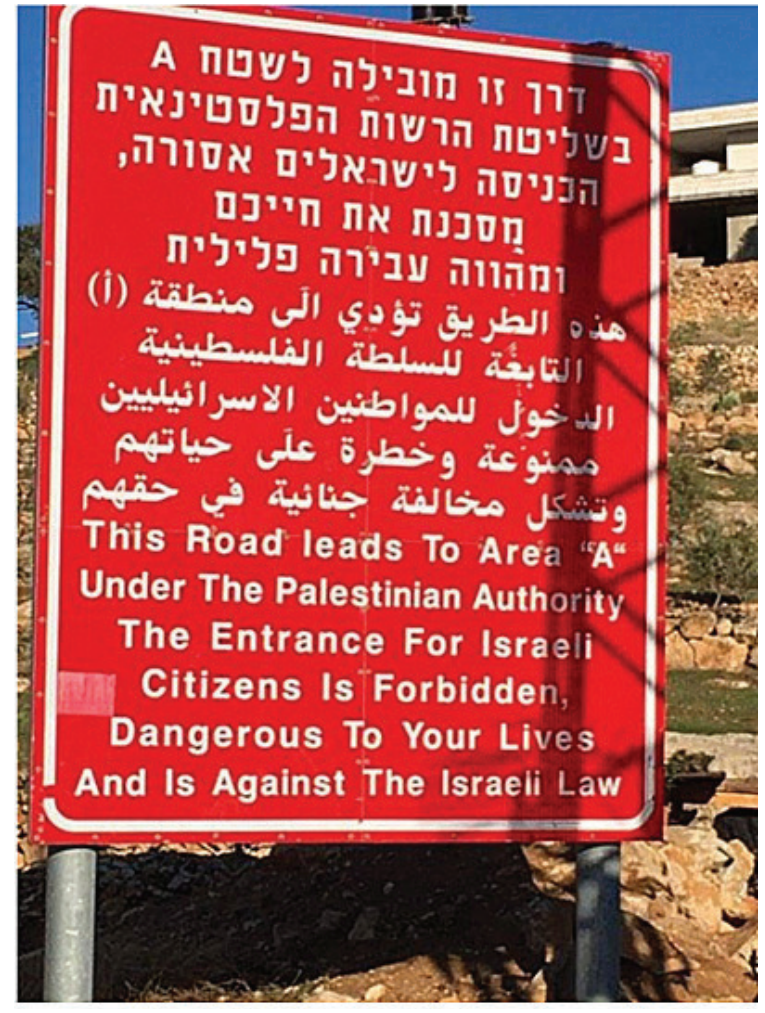

A presença de israelenses é proibida nas Áreas A da Cisjordânia. Enormes placas vermelhas anunciam que a entrada é proibida, oferece risco de vida e é contra a lei israelense.

Uma dessas atividades foi um dia de trabalho em uma fazenda palestina na vila de Al-Walaja, ao sul de Jerusalém. Encontreime com Boris pela manhã, no Checkpoint 300, do lado israelense. Dali, fomos para um ponto de encontro na saída de Jerusalém, que ficava a apenas um quilômetro da fazenda. Precisávamos passar por um checkpoint e estaríamos no local, onde os membros palestinos da ONG nos esperavam. Contudo, quando o grupo israelense estava todo reunido, nos dirigimos ao checkpoint e os soldados não permitiram a passagem. Alegaram que o acesso à estrada estava proibido, por ser uma estrada exclusiva. “Exclusiva para quem?", perguntou Boris, mas não teve resposta. Então, o comboio de carros fez a volta, entrou em Beit Jala e andamos por mais de 30 minutos até chegar ao local.

Boris ficou bastante apreensivo com as placas vermelhas indicando que sua entrada era proibida. Isso porque a Cisjordânia, desde os acordos de Oslo, é dividida em Áreas A, B e C. As Áreas A são aquelas administradas pela Autoridade Palestina, em geral, as cidades: Belém, Jericó, Ramalá, Nablus, Jenin, etc. A presença de israelenses nesses locais é proibida e enormes placas vermelhas indicam em três línguas que "a entrada de israelenses é proibida, perigosa para suas vidas e é contra 
a lei israelense". As Áreas B são áreas de vilas árabes, sob ocupação israelense. As Áreas C são propriedades privadas, em geral fazendas palestinas ou assentamentos israelenses. De acordo com a lei israelense, se as terras palestinas não estão em uso, são confiscadas e usadas para a construção de novos assentamentos.

Alguns israelenses ignoram as placas e entram nas Áreas A. É o caso de Rami Elhanam, mencionado acima, o co-diretor israelense da ONG The Parents Circle Families Forum. Um dos escritórios da ONG é em Beit Jala, Área A, e ele trabalha ali três dias na semana. Ao ser parado no checkpoint, na estrada que dá acesso a Beit Jala a partir de Jerusalém, Rami desafia os soldados para que o impeçam de seguir em frente. Segundo ele, isso nunca aconteceu, pois seria um escândalo internacional.

A propriedade que visitamos naquele dia está na Área C e pertence à família Abedraboo. Os Abedraboo estão lutando para manter a terra, ainda que não seja autossustentável, muito menos rentável. Para ajudar a família, os ativistas de Combatants for Peace visitam o local regularmente, onde trabalham a terra, brincam com crianças da vila, compram produtos de um pequeno mercado de verduras e artesanato organizado pela família e compram falafels ${ }^{14}$ preparados e vendidos na hora. Ao longo do dia, sentamse para discutir sobre o futuro de suas nações e a relevância do trabalho que fazem. Ao questionar sobre como aquele tipo de atividade, envolvendo cerca de 60 pessoas, poderia mudar o status quo da ocupação israelense ou influenciar decisões política, um palestino me diz: "Não pode. Nosso foco aqui, hoje, não é resolver o conflito, mas ajudar a família Abedraboo a manter suas terras e impedir que um novo assentamento seja construído. Estamos trabalhando juntos pela paz, mas a um nível pessoal".

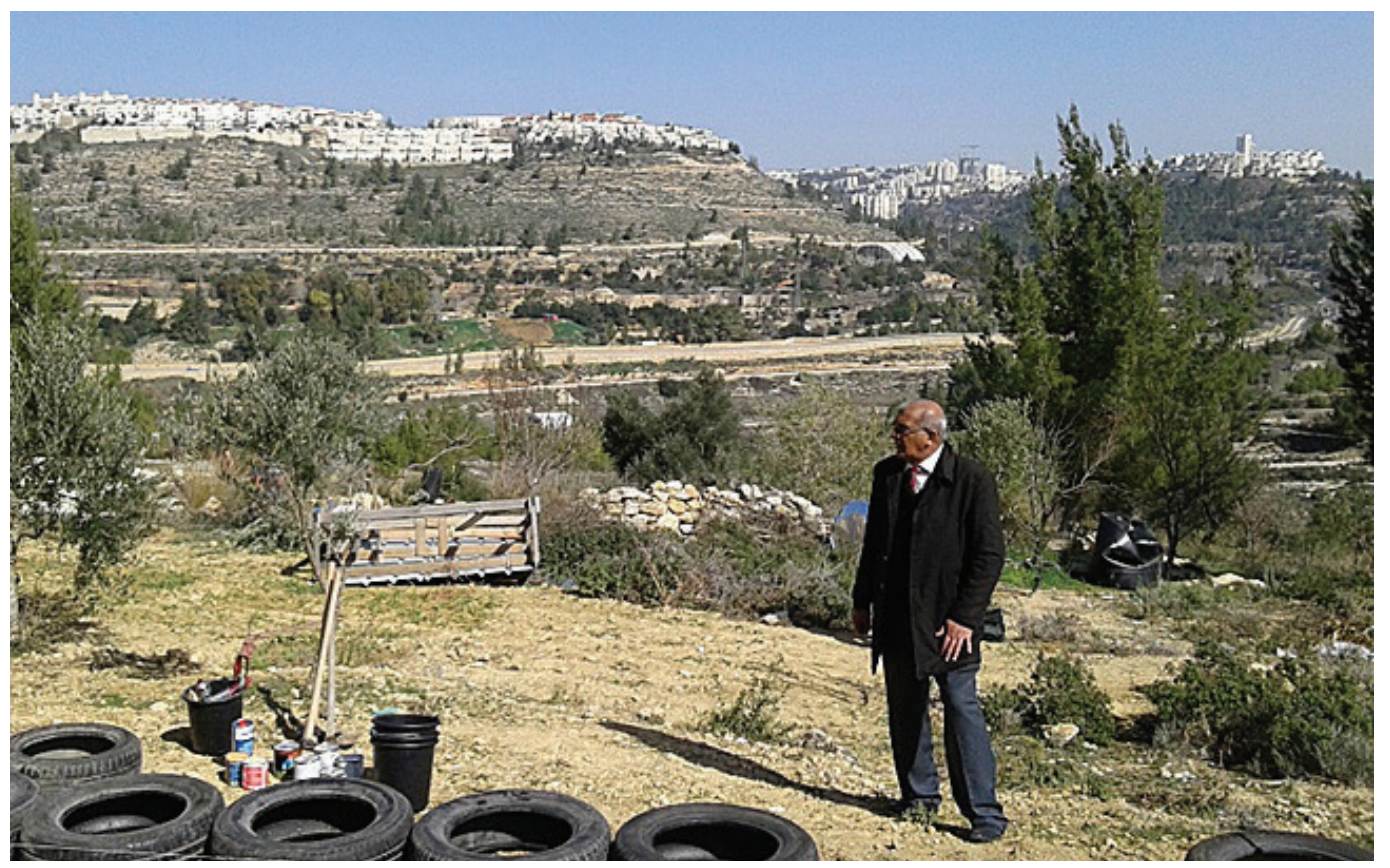

Nas Áreas C da Cisjordânia, as terras não cultivadas são confiscadas por Israel para a construção de novos assentamentos. Na foto, um professor da Universidade Hebraica de Jerusalém visitando a propriedade dos Abedraboo, na vila Al-Walaja. Ao fundo, no topo da colina, o assentamento israelense de Gilo.

${ }^{14}$ Um tipo de pastel tradicional na Terra Santa. 
Já uma participante israelense, que veio de Tel-Aviv para reencontrar os amigos palestinos, foi bem mais crítica:

Sinto-me ingênua só por estar aqui e acreditar que isso fará qualquer diferença.
A sensação de estar aqui é agradável. O dia está bonito, a música é boa, a comida
também. Mas essa nossa conversa só é amigável porque todos pensamos da
mesma maneira, politicamente falando. Nós chamamos isso de grupo de diálogo.
Mas é muito fácil conversar assim! Cadê a direita israelense conversando com o
Hamas? Cadê as mulheres da esquerda israelenses conversando com as mulheres
muçulmanas palestinas? Se não há esses requisitos mínimos para se dialogar
- diferentes pensamentos, mas igualdade de posições - então eu sou ingênua
demais se decido acreditar que isso aqui é diálogo. E se eu acreditar que isso
muda alguma coisa, não sou só ingênua, mas tola.

Para os palestinos, o diálogo é cada vez mais considerado um instrumento de normalização, um meio de dizer que o estado anormal de ocupação é normal. A cooperação, em vez do boicote a Israel, é frequentemente vista na comunidade como traição e menos palestinos estão dispostos a defendê-la.

No entanto, talvez o maior desafio para os grupos da paz hoje seja lidar com o cansaço e a desesperança em relação ao fim da ocupação na Palestina. Usama Nicola, da organização palestina $W^{\prime}{ }^{\prime} a m^{15}$, contou-me em outra ocasião que pelo menos $70 \%$ dos palestinos não se importam mais com sua situação política. "Eles procuram viver alheios à realidade da ocupação e tentam continuar com suas vidas o melhor possível. Para muitos, especialmente os cristãos, a melhor opção é deixar a Palestina. Estamos desistindo de acreditar em paz", lamenta ele.

Sobre o mesmo assunto, Janet Aviad, da organização Peace Now ${ }^{16}$, a primeira a estabelecer contatos com palestinos ainda na década de 1970, vê na evasão de pessoas um retrato dessa apatia: "As pessoas desistiram. Elas se sentem irrelevantes. Ir mais uma vez a uma manifestação, que diferença faz? A desesperança que temos agora não nos dá a base para um movimento de paz. Precisamos de pessoas que acreditam", relata.

No final da visita aos Abedraboo, como eu retornava para Belém, deixei Boris e peguei carona com os palestinos. Cruzamos Beit Jala, evitando os checkpoints, pois no carro estavam dois rapazes palestinos e uma israelense indo encontrar-se com alguém em Ramalá. Durante todo o caminho, eles riam e faziam graça da situação: dois palestinos e uma israelense dentro do mesmo carro, na Cisjordânia. Seguindo os estereótipos, isso jamais poderia resultar em algo bom!

\section{Partilhando com o inimigo}

Outra família palestina, os Nassar, resolveram ser mais proativos para lidar com a ocupação. A família possui uma propriedade de cerca de 100 hectares a poucos quilômetros de Belém, na estrada que leva até Hebron, Área C. Estão ali desde o tempo do Império Otomano, mas hoje disputam na justiça em Israel para continuar com a propriedade.

\footnotetext{
${ }^{15}$ Website: <http://www.alaslah.org>.

${ }^{16}$ Website: <http://peacenow.org.il/en>.
} 
Há cinco assentamentos israelenses construídos nos arredores da propriedade e as pressões, tanto do exército quanto por parte dos vizinhos judeus, são muitas. Não há fornecimento de água e energia para a fazenda. A estrada de terra que dá acesso ao lugar, a partir de Belém, foi bloqueada com pedaços de concreto e restos de lixo. É preciso deixar o carro na metade do caminho e seguir a pé. Uma lei israelense determinada que nada pode ser construído nas Áreas C pelos palestinos.

Os Nassar aderiram ao movimento de resistência não violenta, criaram uma ONG

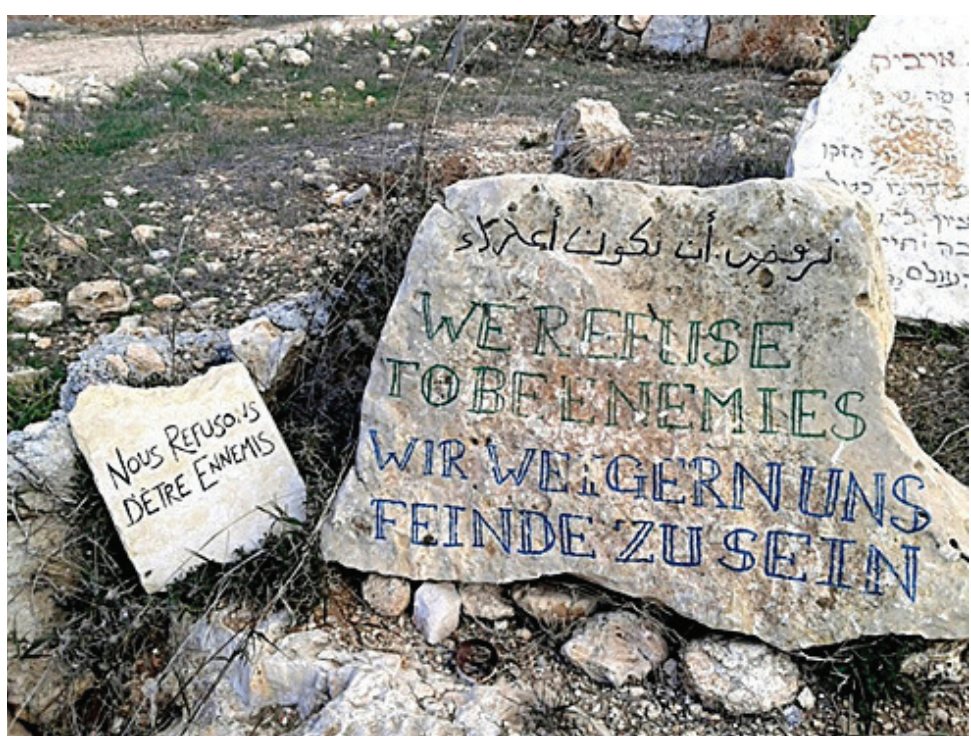

Na entrada da propriedade dos Nassar, o lema da família: "Nós nos recusamos a ser inimigos". chamada Tent of Nations ${ }^{17} \mathrm{e}$ lutam para tornar a fazenda autossustentável, produzindo vinhoeazeitedeoliva.Luteranos, recebem mensalmente doações financeiras principalmente de igrejas católicas da Alemanha.

Visitei Tent of Nations pela primeira vez no início de janeiro. A casa da família, simples e prática, tem uma vista privilegiada: de um lado, as lindas paisagens de Israel, a Faixa de Gaza e o Mediterrâneo se veem ao longe, quando o dia está claro. Do outro, o Mar Morto e as fantásticas montanhas da Jordânia, que ganham uma tonalidade cor de rosa quando o sol está se pondo.

Logo que chegamos, os irmãos Dahud e Daher Nassar nos mostraram a propriedade e, com bom humor, contaram as estratégias para driblar as pressões da ocupação. Como não têm energia, criaram um sistema para produzir energia solar. A água, da chuva, é mantida em cisternas subterrâneas, de forma que os soldados não as vejam nas visitas semanais que fazem. Como não podem construir, os Nassar voltaram às tradições de seus pais e avós: habitar em cavernas. Abrem cavernas embaixo da terra, entre as pedras, aonde recebem seus convidados, amigos e voluntários.

Daher contou que, em dezembro, moradores dos assentamentos, judeus com posições mais radicais, invadiram a fazenda. Ameaçaram a família, arrancaram e queimaram 1.500 pés de oliveira. Perguntei a ele o que iria fazer sem as oliveiras. Sem perder o senso de humor, respondeu: "Eu chamo meus amigos judeus, outros, que são mais tranquilos. Eles vêm, me ajudam a plantar de novo, nós comemos juntos, tomamos café árabe e batemos um papo. Aí eles vão embora. Também temos voluntários ajudando a replantar. Você também pode ajudar. Quer vir plantar oliveiras?”. Alguns dias depois, retornei com mais três amigos e plantamos 20 oliveiras.

\footnotetext{
${ }^{17}$ Website: <http://www.tentofnations.org>.
} 
Na entrada da fazenda dos Nassar, escrito em pedras em diversas línguas está o lema da família e da ONG: "We refuse to be enemies". Após plantar minhas oliveiras, com a ajuda de Daher escolhi uma pedra e deixei a inscrição também em língua portuguesa.

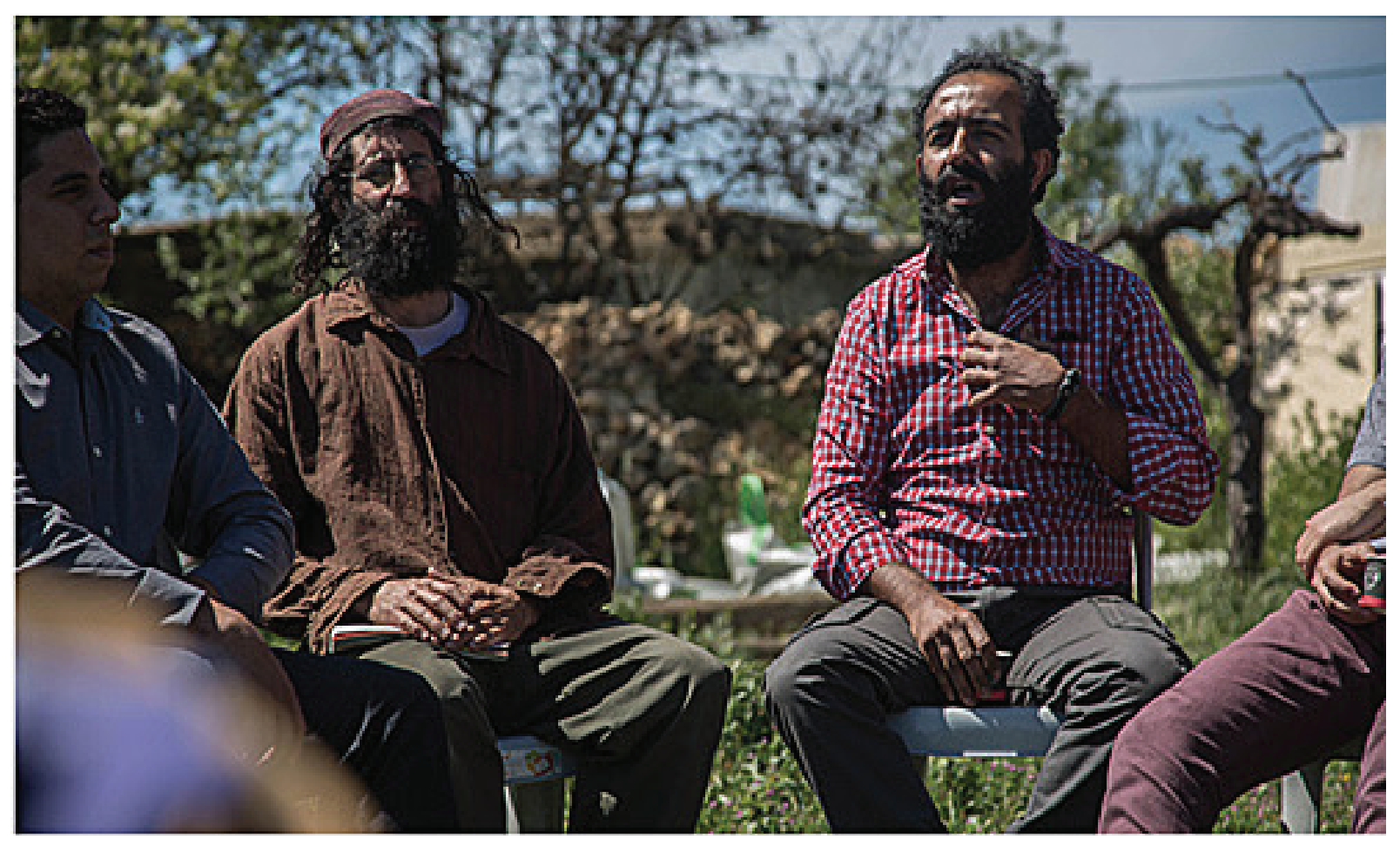

Palestinos e colonos judeus juntos para dialogar: 'Se os que querem a paz não dialogam com os extremos, alguém precisa ir e dialogar”, diz um dos membros da ONG Roots. Imagem: Friends of Roots.

Há palestinos que vão além dos Nassar e decidem quebrar todas as barreiras e dialogar com o "inimigo" dos assentamentos, os colonos judeus. Foi o que fez Ali Abu Awwad, um dos fundadores da ONG Roots ${ }^{18}$, a qual trabalha em parceria com Holy Land Trust, escolhida para minha pesquisa. Abu Awwad construiu uma pequena cabana em um pedaço de terra próximo a Gush Etzion, um dos maiores assentamentos judaicos na Cisjordânia, e passou a convidar seus vizinhos para comer, conversar e orarem juntos. "Se aqueles israelenses que querem a paz não estão conversando com os colonos porque dizem que eles são muito extremistas, então alguém tem que ir lá e conversar", diz ele em entrevistas ${ }^{19}$. 0 diálogo entre os extremos é algo relativamente novo, pois até então apenas os de posições moderadas, de ambos os lados, concordavam em conversar, sobre pontos comuns, e os extremos eram deixados de lado.

\section{Pontes e rachaduras no Muro}

Para a pesquisa, li extensamente sobre o papel das narrativas históricas em conflitos intratáveis - aqueles em que as reivindicações vão além de questões territoriais, mas

\footnotetext{
${ }^{18}$ Website: <https://www.friendsofroots.net>.

${ }^{19}$ Ver mais em: <http://www.haaretz.com/israel-news/.premium-1.788517>.
} 
se formam a partir de crenças relacionadas a identidade nacional e direitos a um território específico ${ }^{20}$. Isso cria um senso de vitimização, que é predominante hoje no conflito. Cada lado vê a si mesmo como vítimas históricas e vítimas definitivas do outro. Para os israelenses, o conflito com os árabes, e mais particularmente com os palestinos, está intrinsicamente ligado à sua história de sofrimento, exílio e perseguição, culminando com o Holocausto. Já os palestinos se percebem como vítimas de um longo processo de ocupação, vindo desde os impérios da antiguidade, depois com o mandato britânico e culminando com a guerra de 1947-48, um processo que, desde o início, nega sua existência nacional.

Antes da experiência de pesquisa, estava bastante familiarizada com a narrativa judaica, por ter crescido em uma igreja cristã sionista. Para além disso, o trauma judaico vivido no Holocausto sempre me comoveu. Em uma das últimas semanas na Terra Santa, visitei o Yad Vashem, o memorial das vítimas do Holocausto. No Jardim dos Justos Entre as Nações, onde são homenageados não judeus que salvaram judeus durante a Segunda Guerra Mundial, encontrei nomes muito familiares, de alguns de meus heróis pessoais, como Corie Ten Boom e Irena Sendler. Passei sete horas no museu, revivendo uma história em conhecida. Podia simpatizar com a narrativa judaica e a necessidade de um Estado livre de perseguição. Da mesma forma, viver a realidade da ocupação fez-me simpatizar com a narrativa palestina e viver as pressões físicas e psicológicas de ser o inimigo a ser derrotado.

Podem essas narrativas tão distintas coexistirem? Pode um acordo de paz acontecer? Se analisarmos a situação política de Israel e Palestina, do Oriente Médio e de todo o mundo neste momento é difícil acreditar em paz em um futuro próximo. Contudo, o movimento pela paz convenceu-me de que, para além das decisões políticas, as barreiras do ódio e da segregação precisam ser derrubadas. E, nisso, cada uma das ONGs que visitei tem um importante papel. Elas refazem o caminho de reconectar essas sociedades que, por milênios, conviveram pacificamente. "As pessoas que desejam a paz ainda estão lá", diz Janet Aviad, de Peace Now. "Tudo que as pessoas precisam é sentir que ainda são relevantes. Temos que ser honestos sobre o impacto que temos agora, mas isso não significa que iremos parar. 0 clima de paz pode voltar algum dia. Espero que volte".

Rami Elhanan, do PCFF, descreve seu trabalho como "criar rachaduras no Muro". Para ele, reunir "inimigos" para dialogar é uma maneira de criar pequenos espaços na realidade segregada, os quais oferecem a muitos a possibilidade singular de ver o que está do outro lado e se reconciliar com isso. Talvez, o movimento pela paz tenha lições a ensinar a todos nós, em um momento histórico em que a humanidade está, mais uma vez, cheia de "muros" e estereótipos.

Texto recebido em: 29 de Junho de 2017 Aprovado em: 19 de Julho de 2017

\footnotetext{
${ }^{20}$ BAR-TAL, Daniel. From Intractable Conflict Through Conflict Resolution to Reconciliation: Psychological Analysis. Political Psychology, vol. 21, n. 2, p. 351-365, 2000.
} 